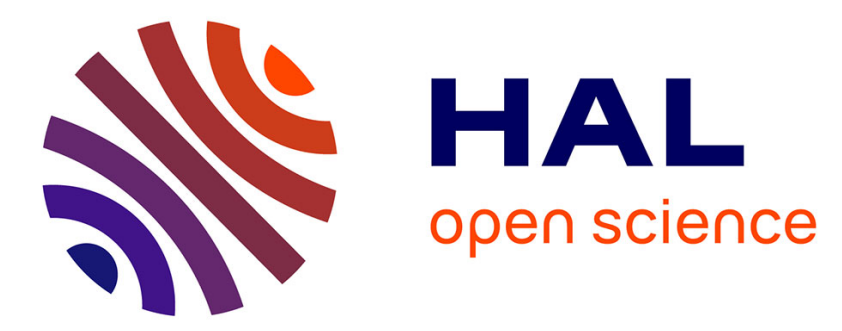

\title{
Quantification of vertical solid matter transfers in soils during pedogenesis by a multi-tracer approach
}

Marianna Jagercikova, Sophie Cornu, Didier Bourlès, O. Evrard, Christine Hatté, Jérôme Balesdent

\section{To cite this version:}

Marianna Jagercikova, Sophie Cornu, Didier Bourlès, O. Evrard, Christine Hatté, et al.. Quantification of vertical solid matter transfers in soils during pedogenesis by a multi-tracer approach. Journal of Soils and Sediments, 2017, 17 (2), pp.408-422. 10.1007/s11368-016-1560-9 . hal-01457997

\section{HAL Id: hal-01457997 https://hal.science/hal-01457997}

Submitted on 18 May 2018

HAL is a multi-disciplinary open access archive for the deposit and dissemination of scientific research documents, whether they are published or not. The documents may come from teaching and research institutions in France or abroad, or from public or private research centers.
L'archive ouverte pluridisciplinaire HAL, est destinée au dépôt et à la diffusion de documents scientifiques de niveau recherche, publiés ou non, émanant des établissements d'enseignement et de recherche français ou étrangers, des laboratoires publics ou privés.

$$
\text { Copyright }
$$


1

2

3

4

5

9

SOILS, SEC \# • RESEARCH ARTICLE

Quantification of vertical solid matter transfers in soils during pedogenesis by a multitracer approach

Marianna Jagercikova ${ }^{1} \cdot$ Cornu Sophie $^{1} \bullet$ Didier Bourlès $^{1} \bullet$ Olivier Evrard $^{2} \cdot$ Christine $^{-}$ Hatté $^{2}$ • Jérôme Balesdent ${ }^{1}$

${ }^{1}$ Aix-Marseille Université, CNRS, College de France, IRD, INRA, CEREGE, 13545 Aix en Provence, France

${ }^{2}$ Laboratoire des Sciences du Climat et de 1'Environnement (LSCE/IPSL), UMR8212

(CEA-CNRS-UVSQ), Université Paris-Saclay, 91198 Gif-sur-Yvette Cedex, France 13

$5 \square$ Sophie Cornu

6 sophie.cornu@aix.inra.fr

$7+330442971796$ 


\section{Abstract}

Purpose - Vertical transfer of solid matter in soils (bioturbation and translocation) is responsible for changes in soil properties over time through the redistribution of most of the soil constituents with depth. Such transfers are, however, still poorly quantified.

Materials and methods - In this study, we examine matter transfer in four eutric Luvisols through an isotopic approach based on ${ }^{137} \mathrm{Cs},{ }^{210} \mathrm{~Pb}_{(\mathrm{xs})}$, and meteoric ${ }^{10} \mathrm{Be}$. These isotopes differ with respect to chemical behaviour, input histories and half-lives, which allows us to explore a large time range. Their vertical distributions were modelled by a diffusionadvection equation with depth-dependent parameters. We estimated a set of advection and diffusion coefficients able to simulate all isotope depth distributions and validated the resulting model by comparing the depth distribution of organic carbon (including ${ }^{12 / 13} \mathrm{C}$ and ${ }^{14} \mathrm{C}$ isotopes) and of the 0-2 $\mu \mathrm{m}$ particles with the data.

Results and discussion - We showed that i) the model satisfactorily reproduces the organic carbon, ${ }^{13} \mathrm{C}$ and ${ }^{14} \mathrm{C}$ depth distributions, indicating that organic carbon content and age can be explained by transport without invoking depth-dependent decay rates; ii) translocation partly explains the $0-2 \mu \mathrm{m}$ particle accumulation in the Bt-horizon; and iii) estimates of diffusion coefficients that quantify the soil mixing rate by bioturbation are significantly higher for the studied plots than those obtained by ecological studies.

Conclusions - This study presents a model capable of satisfactorily reproducing the isotopic profiles of several tracers and simulating the distribution of organic carbon and the translocation of $0-2 \mu \mathrm{m}$ particles.

Keywords $0-2 \mu \mathrm{m}$ fraction $\bullet$ Bioturbation $・$ Clay translocation $\bullet$ Cosmonuclides $\bullet$ Fallout radionuclides $\bullet \delta^{13} \mathrm{C} \cdot$ Organic carbon $\bullet$ Numerical modelling 


\section{Introduction}

Vertical matter transfer processes in soils, such as bioturbation and 0-2 $\mu \mathrm{m}$ particle translocation, are responsible for the evolution through time of the ecosystem services provided by the soils through the redistribution of most of their components with depth, especially the finest particle fractions and organic matter, which are responsible for the main properties of soil surface layers. Progressive transfer of matter with depth leads to the development of texturecontrasted soils (Jamagne and Pedro 1981; Bockheim and Gennadiyev 2000) and to the redistribution of organic carbon with depth. Indeed, a recent state-of-the-art model of soil organic carbon dynamics (e.g., Koven et al. 2013) concludes with the need to estimate carbon vertical transport.

Despite their importance in soil formation processes and in the control of the organic carbon depth distribution, the dynamics of the vertical transfer of soil matter are still poorly constrained and modelled (Samouelian and Cornu, 2008). Salvador-Blanes et al. (2007) reported that most of the existing models of pedogenesis failed at describing the horizon formation because they did not consider the redistribution of matter with depth. To improve modelling of these processes, there is a need to better quantify the transfer of matter in soils and to constrain their kinetics. To this end, the measurement of tracers that are supplied to the soil surface through meteoric deposition and that have a strong affinity for soil constituents can provide relevant information to improve our knowledge of those processes. Fallout radionuclides ${ }^{10} \mathrm{Be},{ }^{137} \mathrm{Cs}$ and ${ }^{210} \mathrm{~Pb}_{(\mathrm{xs})}$, which are characterized by different half-lives, may be used as chronometers in this context.

Meteoric ${ }^{10} \mathrm{Be}$ (half-life $=1.39 \mathrm{Myr}$ (Korschinek et al., 2010) is a cosmogenic nuclide created in the upper atmosphere by the interaction of primary and secondary cosmic ray particles with oxygen and nitrogen atoms (Lal and Peters 1967). It is delivered to the terrestrial surface through wet/dry fallout. ${ }^{137} \mathrm{Cs}$ (half-life $=30.2$ years) was released and dispersed during 
thermonuclear atmospheric tests that occurred between 1953 and the 1970s and during nuclear power plant accidents (Chernobyl in 1986 or Fukushima Dai-ichi in 2011). Finally, ${ }^{210} \mathrm{~Pb}$ (halflife $=22.3$ years) is naturally present as it decays from its ultimate parent ${ }^{238} \mathrm{U}$, and it constitutes a daughter product of gaseous ${ }^{222} \mathrm{Rn}$. Some ${ }^{222} \mathrm{Rn}$ may escape from the soil and then decay in the atmosphere, producing ${ }^{210} \mathrm{~Pb}$, which then returns to the surface of the Earth through wet fallout. This isotope is therefore referred to as unsupported or excess (xs) ${ }^{210} \mathrm{~Pb}$, in contrast to supported ${ }^{210} \mathrm{~Pb}$, which is naturally present in the soil. Due to their different input histories and half-lives, these isotopes provide temporal constraints ranging from the duration of soil formation $\left({ }^{10} \mathrm{Be}\right)$ to the duration of human activity $\left({ }^{137} \mathrm{Cs}\right.$ and $\left.{ }^{210} \mathrm{~Pb}_{(\mathrm{xs})}\right)$.

${ }^{137} \mathrm{Cs}$ and ${ }^{10} \mathrm{Be}$ are known to sorb on clay particles (Tamura and Jacobs 1960; Sawhney 1972; Pavich et al. 1984; Cremers et al. 1988; You et al. 1989; Takahashi et al. 1999) and ${ }^{210} \mathrm{~Pb}_{(\mathrm{xs})}$ on both clay particles and organic matter (Dörr and Münnich, 1989). They were therefore used in the past to trace erosion (e.g. He and Walling, 1997) and bioturbation (Jarvis et al., 2010). Their depth distribution is classically described by an advection diffusion in the literature (e.g. He and Walling, 1997). However, to the best of our knowledge, these three tracers were rarely used in combination in the literature.

In previous studies, Jagercikova et al. (2014a and 2015) fitted a diffusion-advection equation to the depth distributions of ${ }^{137} \mathrm{Cs}$ and ${ }^{210} \mathrm{~Pb}_{(\mathrm{xs})}$ and of meteoric ${ }^{10} \mathrm{Be}$ along a Luvisol sequence developed on loess with varying histories of land use and soil management. ${ }^{137} \mathrm{Cs}$ and ${ }^{210} \mathrm{~Pb}_{(\mathrm{xs})}$ advection velocities (Jagercikova et al. 2014a) were one order of magnitude higher than those of meteoric ${ }^{10} \mathrm{Be}$ (Jagercikova et al. 2015). To understand the origin of the discrepancy in the diffusion-advection coefficients obtained by Jagercikova et al. (2014a) and (2015), we return in this study to model rationales and initialisation conditions to infer the major discrepancies. Indeed, i) diffusion-advection coefficients used for ${ }^{137} \mathrm{Cs}$ and ${ }^{210} \mathrm{~Pb}_{(\mathrm{xs})}$ varied in depth with organic matter and pH (Jagercikova et al. 2014a) but decreased exponentially with 
depth for meteoric ${ }^{10} \mathrm{Be}$ (Jagercikova et al. 2015); ii) ${ }^{137} \mathrm{Cs} /{ }^{210} \mathrm{~Pb}_{(\mathrm{xs})}$ and meteoric ${ }^{10} \mathrm{Be}$ simulations were not performed for the same time period (last 60 years for ${ }^{137} \mathrm{Cs}$ and ${ }^{210} \mathrm{~Pb}_{(\mathrm{xs})}$ and $15 \mathrm{kyr}$ for meteoric ${ }^{10} \mathrm{Be}$ ); and iii) histories of isotope input differed: ${ }^{137} \mathrm{Cs}$ and ${ }^{210} \mathrm{~Pb}_{(\mathrm{xs})}$ had no inherited fraction, whereas more than two-thirds of the meteoric ${ }^{10} \mathrm{Be}$ was inherited (Jagercikova et al. 2015). To integrate the information provided by both ${ }^{137} \mathrm{Cs}$ and meteoric ${ }^{10} \mathrm{Be}$ in a single model, we designed a single diffusion-advection model based on the difference in input history, including inheritance, of the different isotopes to simulate the ${ }^{137} \mathrm{Cs},{ }^{10} \mathrm{Be}$ and ${ }^{210} \mathrm{~Pb}_{(\mathrm{xs})}$ depth-distribution profiles along four of the Luvisols, that had been measured by Jagercikova et al. (2014a and 2015).

We then used the obtained coefficients to estimate the solid matter transfer of both the 0 $2 \mu \mathrm{m}$ fraction and organic carbon. For organic carbon depth-distribution modelling, we tested as a simplifying hypothesis that carbon mineralization, i.e., carbon decay rate, is not depthdependent. Because organic carbon dynamics are usually constrained by isotope measurements (Koven et al. 2013; Ahrens et al. 2014), ${ }^{13} \mathrm{C}$ and ${ }^{14} \mathrm{C}$ depth distributions were also modelled.

\section{Materials and methods}

\subsection{Numerical modelling}

\subsubsection{Diffusion-advection equation and tillage mixing term}

Numerical modelling was performed using a diffusion-advection equation including radioactive decay (He and Walling 1997; Schuller et al. 1997; Jagercikova et al. 2014a):

$$
\frac{\partial C}{\partial t}=\frac{\partial}{\partial z}\left(D_{s} \frac{\partial C}{\partial z}-v_{s} C\right)-\lambda C
$$

with $C$ being the isotopic concentration per soil volume (isotope. $\mathrm{cm}^{-3}$ ) obtained by multiplying the isotopic concentration by the soil bulk density $\left(\mathrm{g} . \mathrm{cm}^{-3}\right) ; z$ the depth $(\mathrm{cm})$; $t$ the time $(\mathrm{yr}) ; D_{s}$ the diffusion coefficient $\left(\mathrm{cm}^{2} \cdot \mathrm{yr}^{-1}\right) ; v_{s}$ the advection velocity $\left(\mathrm{cm} . \mathrm{yr}^{-1}\right)$; 
and $\lambda$ the radioactive constant $\left(\mathrm{yr}^{-1}\right)$ in the case of radioisotopes.

Both the diffusion and advection coefficients are considered to vary with depth, as follows:

$$
\begin{array}{ll}
v_{s}(z)=v_{0}+1 / 20\left(v_{20}-v_{0}\right) z & \text { for } z \text { in }[0,20] \\
v_{\mathrm{s}}(z)=v_{20} \exp (-d z) & \text { for } z \geq 20
\end{array}
$$

with $v_{0}$ being the surface advection velocity, $v_{20}$ the advection velocity at $20 \mathrm{~cm}$ depth and $d$ the constant of the exponential term $\left(\mathrm{cm}^{-1}\right)$; and

$$
D_{s}(z)=D_{0} \exp (-b z) \quad z
$$

with $D_{0}$ being the diffusion coefficient at the surface and $b$ the constant of the exponential term $\left(\mathrm{cm}^{-1}\right)$. The negative exponential term in the advection and diffusion coefficients determines the diminution with depth. In the case of advection, this is due to decreasing hydraulic conductivity in the soil profile and leads to the accumulation of the $0-2 \mu \mathrm{m}$ particles and radioisotopes (e.g., meteoric ${ }^{10} \mathrm{Be}$, as discussed in Jagercikova et al. 2015). The decreasing diffusion coefficient reflects the decreasing organic matter content on which earthworms feed (Jagercikova et al. 2014a), earthworms being the main bioturbation agent in the temperate zone (Gobat et al. 2004; Wilkinson et al. 2009).

Finally, a tillage term is introduced into the model. This term mixes annually $85 \%$ of the soil matter homogeneously over the whole tilled layer as proposed in the Soil and Water Assessment Tool (SWAT) models (Ullrich and Volk 2009 and references therein) and detailed in equation 4.

$$
C(z, t+\Delta t)=\left(1-M_{R}\right) C(z, t)+\frac{M_{R}}{T_{D}} \int_{0}^{T_{D}} C(z, t) d z \quad \forall z \in\left[0 ; T_{D}\right]
$$

with $M_{R}$ being the mixing ratio $(85 \%)$ and $T_{D}$ the tillage depth.

\subsubsection{Soil pools subjected to advection}

Advection corresponds to the vertical transfer of the isotopes that can either occur under solute 
143 form or in association with particles. Bundt et al. (2000) showed that ${ }^{137} \mathrm{Cs}$ is mainly found 144 along preferential flow paths in soils where both the majority of particle transfers (Jacobsen et al. 1997; Majdalani et al. 2007) and rapid water flow occurs (Sammartino et al., 2015). Accordingly, we hypothesize that only the fraction of the isotopes surrounding macropores are subjected to advection. We thus assumed that all the isotopes brought by meteoric deposition after the loess was deposited are subjected to advective transfer. On the other hand, the inherited isotopes are supposed to be homogeneously distributed in the initial loess deposit. Thus, only $20 \%$ of them are assumed to surround the macropores and are therefore as assumed to be submitted to advection. As mentioned in the introduction, ${ }^{137} \mathrm{Cs}$ has no inherited fraction, whereas more than two-thirds of the meteoric ${ }^{10} \mathrm{Be}$ is inherited (Jagercikova et al. 2015). To summarize, we assume for each isotope and/or element that i) the isotopes brought to the soil after the loess was deposited are subjected to both diffusive and advective transfers and ii) for ${ }^{10} \mathrm{Be}$ and the $0-2 \mu \mathrm{m}$ fraction, $20 \%$ of the initial loess content is also subjected to both diffusive and advective transfers, while the remaining $80 \%$ is subjected exclusively to diffusion, because bioturbation is considered to affect the entire soil mass.

\subsubsection{Numerical implementation and parameter optimization}

The boundary, initial conditions and isotope input history used for the simulations are reported in Table 1. The differential equation (1) is solved using an upstream finite difference approximation for spatial derivatives and a semi-implicit Crank-Nicholson scheme as a timesolver (implementation is detailed in Jagercikova 2014a). The obtained system of algebraic equations is solved by Gaussian elimination. Simulations start at the end of the loess deposition period, which coincides with the assumed beginning of pedogenesis, i.e., $15 \mathrm{kyr}$ BP. The advection-diffusion coefficients and their standard deviations are determined with a non-linear least-squares minimization procedure based on the Levenberg-Marquardt algorithm. For estimating the performance of the fitting procedure, the modelling efficiency $(E F)$ is calculated 
(Loague and Green 1991; see Jagercikova et al. (2014a) for further details). All parameters are deduced from both ${ }^{137} \mathrm{Cs}$ and ${ }^{10} \mathrm{Be}$ profiles. Combining two isotopes with different periods and input histories allows better constraint of the equation parameters than would be possible using a single isotope. The long period of ${ }^{10} \mathrm{Be}$ allows precise definition of the $D_{0}$ and $d$ terms, whereas ${ }^{137} \mathrm{Cs}$ provides better information on the advection term in the upper $20 \mathrm{~cm}$. The obtained diffusion and advection velocity coefficients are then used to simulate the $0-2 \mu \mathrm{m}$ fraction, organic carbon concentration and $\delta^{13} \mathrm{C}$ and $\Delta{ }^{14} \mathrm{C}$ isotope depth distributions for the different soil profiles.

2.2 Application of the model to four Luvisol profiles in northern France

\subsubsection{Studied soil profiles}

Four of the nine eutric Luvisol profiles studied by Jagercikova et al. (2014a and 2015) were selected. These soil profiles are part of long-term experimental sites in northern France dedicated to the evaluation of the impact of different farming practices on soil characteristics (Table 2, Fig. 1).

These Luvisols developed on Weichselian (Upper Pleniglacial) loess deposited in both the Somme and the Seine River basins (northern France) during glacial eras and until 15-17 kyr BP (Antoine et al. 1999, 2003). They have thus undergone pedogenesis for at least the last $15 \mathrm{kyr}$ and developed from the same parent material under similar climatic and topographic conditions (slope $<1 \%$ ). The four studied soils have different $\mathrm{pH}$ levels (from 8 to 6, Fig. 2) and are developed on different substrates (Table 3). In Mons, Luvisols (under cropland and grassland) are developed from several metres of loess and are thus well drained, whereas in Feucherolles, clay and gritstone deposits are found at approximately $1.5 \mathrm{~m}$ depth. Finally, in Boigneville, chalk is reached at approximately $80 \mathrm{~cm}$ depth. Luvisols in Feucherolles exhibit features of morphologic degradation due to the change of parent material with depth.

Soils are continuously sampled along a pit side with a sampling increment ranging from 2 
to $10 \mathrm{~cm}$ and following the horizon boundaries. Sampling is stopped at $1.7 \mathrm{~m}$ depth or when the underlying parent material is reached. Bulk densities are measured using cylinders of $500 \mathrm{~cm}^{3}$, with three replicates.

\subsubsection{Sample preparation and analysis}

Particle size fractionation - Collected samples are oven-dried for a week at $40^{\circ} \mathrm{C}$ and sieved to $2 \mathrm{~mm}$ as recommended in the NF ISO 11464 procedure. Particle size distribution $(<2 \mu \mathrm{m} ; 2$ $20 \mu \mathrm{m} ; 20-50 \mu \mathrm{m} ; 50-200 \mu \mathrm{m} ; 200-2000 \mu \mathrm{m})$ is measured by wet sieving down to $50 \mu \mathrm{m}$ and according to the Robison's pipette method below $50 \mu \mathrm{m}$ after removal of organic matter using $\mathrm{H}_{2} \mathrm{O}_{2}$ at the INRA Laboratory of Soil Analysis (Arras, France).

Organic carbon content and isotope analysis - Organic carbon content (hereafter referred to as carbon content) is determined by dry combustion (Carlo Erba NA 1500 Elemental Analyzer) of samples ground to less than $200 \mu \mathrm{m}$, and $\delta^{13} \mathrm{C}$ is analysed by coupled mass spectrometry analysis (EA-IRMS, Delta Plus, ThermoFinnigan). The $\delta^{13} \mathrm{C}$ values are reported vs V-PDB, using polyethylene IAEA CH7 $\left(\delta^{13} \mathrm{C}=-32.15 \pm 0.05 \%\right)$ as a secondary standard; the sucrose standard IAEA CH6 (Coplen et al., 2006) yields a mean value of $-10.45 \pm 0.04 \%$. When containing carbonates, the samples are pretreated with repeated amounts of $2 \mathrm{M} \mathrm{HCl}$ added to $100 \mathrm{mg}$ of sample. To avoid the loss of acid-extracted organic carbon, the whole suspension is then dried at $60^{\circ} \mathrm{C}$.

For ${ }^{14} \mathrm{C}$ analyses, the $\mathrm{CO}_{2}$ gas is prepared at the $\mathrm{LSCE}-{ }^{14} \mathrm{C}$ lab using a protocol adapted to achieve carbonate leaching without any loss of organic carbon, with ${ }^{14} \mathrm{C}$ activity measurement performed by AMS at the French LMC14 facility (Cottereau et al., 2007). The ${ }^{14} \mathrm{C}$ activities are presented in $\Delta(\%)$ notation, with measurement and sampling year corrections as recommended by Stuiver and Polach (1977). 
$\delta^{13} \mathrm{C}$ vertical distributions are available for the Mons grassland and Boigneville cropland sites, while the $\Delta{ }^{14} \mathrm{C}$ vertical distribution is available for the Mons grassland site only.

\subsubsection{Application to organic carbon transfer in soil}

Because organic carbon is a complex ensemble of molecules with different decomposition rates, the proposed model accounts for soil organic carbon dynamics by considering organic carbon partitioning between pools with different residence times based on the RothC model (Jenkinson and Rayner 1977; Coleman and Jenkinson 1999; Jenkinson and Coleman 2008). Five carbon pools are considered (Table 4): decomposable plant matter (DPM), resistant plant matter (RPM), decomposers biomass (BIO), stabilized organic matter (HUM) and almost inert organic matter (IOM). All RothC parameter values are set to the default values provided by Coleman and Jenkinson (1999), except the parameter driving IOM, which is kept as proposed by Jenkinson and Rayner (1977) (Table 4).

In the proposed representation, the organic matter decomposition rate evolves with depth as a function of the $0-2 \mu \mathrm{m}$ fraction content that affects the proportion of carbon allocated to the BIO $\left(P_{B I O}\right)$ and HUM $\left(P_{H U M}\right)$ pools (Coleman and Jenkinson 1999; Table 4). The transport parameters $(v$ and $D)$ are the same for the five dynamic pools.

Organic carbon input is distributed between above-ground inputs set at $70 \%$ of the total Cinput and below-ground inputs consisting of the remaining $30 \%$. The latter are distributed according to an exponential law, with $80 \%$ of the below-ground input found in the first $20 \mathrm{~cm}$ for grasslands and areas with maize and wheat crops (Warembourg and Paul 1977; Balesdent and Balabane 1992; Swinnen et al. 1994).

The $\delta^{13} \mathrm{C}$ at each depth is calculated by assuming an enrichment of the $\delta^{13} \mathrm{C}$ associated with organic matter decomposition that is fitted to -1.00010 (the fractionation factor associated with heterotrophic respiration). The ${ }^{13} \mathrm{C} /{ }^{12} \mathrm{C}$ ratios of the biodegradation products allocated to 
$\mathrm{BIO}$ and HUM are then calculated by isotopic mass balance. The newly formed BIO, HUM and IOM are therefore enriched in ${ }^{13} \mathrm{C}$ by $0.32 \%$ to $0.58 \%$ compared to the source pool at each biodegradation step.

\subsubsection{Application to 0-2 $\mu$ m particle transfer in soil}

Two input data are needed to simulate the $0-2 \mu \mathrm{m}$ particle transfer in soil: i) the initial $0-2 \mu \mathrm{m}$ particle content in the loess deposit, set at $24 \%$ (Mons and Feucherolles) and $28 \%$ (Boigneville), and ii) the pool of 0-2 $\mu \mathrm{m}$ particles surrounding macropores, which corresponds to the pool submitted to advection, set at $20 \%$ as for ${ }^{10} \mathrm{Be}$ (Table 1).

\section{Results and discussion}

3.1 Obtained advection and diffusion coefficients

Evolution with depth of the advection velocity and diffusion optimized for the four sites is shown in Fig. 3 and Table 5. Comparisons between simulated data and observations $\left({ }^{10} \mathrm{Be}\right.$, ${ }^{137} \mathrm{Cs}$, and ${ }^{210} \mathrm{~Pb}_{(\mathrm{xs})}$ when available) are shown for Mons grassland, Boigneville cultivation, Mons cultivation, and Feucherolles cultivation in Figs. 4, 5, 6 and 7, respectively. The proposed model fits the isotope depth distribution with modelling efficiencies $(E F)$ greater than 0.9 for meteoric ${ }^{10} \mathrm{Be}$ and equal or greater than 0.8 for ${ }^{137} \mathrm{Cs}$ (Table 5). These efficiencies strengthen confidence in the model and its rationales. ${ }^{210} \mathrm{~Pb}_{(\mathrm{xs})}$ is reasonably modelled for Mons grassland, the only Luvisol profile having ${ }^{210} \mathrm{~Pb}_{(\mathrm{xs})}$ concentrations higher than the detection limit (Jagercikova et al. 2014a). The fact that we could reasonably well predict the distribution of all the studied isotopes with a single set of diffusion-advection coefficients suggests that the isotopes are mainly transported with solid matter in the studied soils, more than as soluble form. Campforts et al. (2016) recently demonstrated using a Kd modelling approach that, for soils with high Kds (i.e., for soil with $\mathrm{pH}$ higher than 5), 5/6 of the isotopic redistribution in depth 
occurrs through particle transfer, even on timescales as long as $10^{4}$ years. This is typically the case of the studied soils where $\mathrm{pH}$ does not decrease below 5 as shown in Figure 2. Pavich et al. (1986), Graly et al. (2010), Jarvis et al. (2010), Willenbring and von Blanckenburg (2010), and Matisoff et al. (2011) also found that the transfer of these isotopes in soils mainly occurs in association with the solid matter, especially in soils with negligible contents in dissolved organic carbon, as observed in the neutral eutric Luvisols developed on loess investigated in the current research. Nevertheless, chemical mobility in soluble phases cannot be ruled out, and the coefficients determined here are therefore considered as proxies maximizing particulate transfer.

The advection velocity ranges from 0.12 to $0.27 \mathrm{~cm} \mathrm{yr}^{-1}$ at $20 \mathrm{~cm}$ depth (Fig. 3, Table 5). Kaste et al. (2007) have estimated advection velocities (though not depth-dependent) to vary between 0.07 and $0.2 \mathrm{~cm} \mathrm{yr}^{-1}$ at their study sites by conducting a combined ${ }^{210} \mathrm{~Pb}_{(\mathrm{xs})}$ and ${ }^{137} \mathrm{Cs}$ modelling approach. Based on the modelling of ${ }^{137} \mathrm{Cs}$ vertical distributions in seven Luvisols collected in different environmental conditions (Milton et al. 2001; Al-Masri 2006; Schimmack and Márquez 2006), Jagercikova et al. (2014b) have found mean advection velocities of $0.22 \pm$ $0.06 \mathrm{~cm} \mathrm{yr}^{-1}$ (not depth-dependent). All these data are of the same order of magnitude. Calculated advection velocities in the first $20 \mathrm{~cm}$ in cultivated plots are of poor significance because advection is hidden by inversion tillage in these soils. The exponential decrease below $20 \mathrm{~cm}$ modelled at all sites, which matches the meteoric ${ }^{10} \mathrm{Be}$ accumulation in the Bt-horizon (Figs. 4b, 5b, 6b and 7b), can be attributed to the decreasing hydraulic conductivity measured at these sites (data not shown), leading to the subsequent accumulation of 0-2 $\mu \mathrm{m}$ particles. Advection velocities become lower than $0.001 \mathrm{~cm} . \mathrm{yr}^{-1}$ at $82 \mathrm{~cm}$ for grassland and at depths ranging from 42 to $73 \mathrm{~cm}$ for cultivation sites (Table 5, Fig. 3), which correspond to Bthorizons. The mean advection velocities vary down to these depths between 0.03 and 0.09 cm. $\mathrm{yr}^{-1}$ (Table 5). 
The surface diffusion coefficient is equal to $3.2 \pm 1.0 \mathrm{~cm}^{2} \cdot \mathrm{yr}^{-1}$ at Mons grassland plot. Although their value was not depth-dependent, Kaste et al. (2007) also estimated the diffusion coefficient at $2.1 \pm 0.4 \mathrm{~cm}^{2} \cdot \mathrm{yr}^{-1}$ for a grassland site in Tennessee valley (California). In cultivated plots, the surface diffusion coefficient varies from $0.26 \pm 0.06$ to $40 \pm 39 \mathrm{~cm}^{2} \mathrm{yr}^{-1}$ (Table 5). This very large range of values is attributed to the prevailing effect of tillage mixing on diffusion that renders the diffusion coefficient difficult to quantify. In agricultural plots, below the surface layer, diffusion becomes negligible $\left(D_{s}<0.01 \mathrm{~cm}^{2} \cdot \mathrm{yr}^{-1}\right)$. The associated mean diffusion coefficients are difficult to quantify (Table 5). Diffusion in terms of bioturbation will therefore be further discussed for the grassland plot only.

3.2 Application of transfer coefficients to modelling of the organic carbon vertical distributions - Validation of the model Comparisons of modelled and observed carbon contents ${ }^{13} \mathrm{C}$ and ${ }^{14} \mathrm{C}$ (when available) are shown in Fig. 8 for Mons grassland and cultivation and in Fig. 9 for Boigneville and Feucherolles cultivation sites. The transfer coefficients determined using ${ }^{137} \mathrm{Cs}$ and ${ }^{10} \mathrm{Be}$ are applied to vertical distributions of organic carbon. The amount of the inherited carbon set by estimation of the C-horizon (Table 1) has a limited effect on final simulation results and only affects deep layers, because the inherited carbon is exhausted. Indeed, less than $1 \%$ of initial $\mathrm{C}$ remains, according to the mineralisation rate constants (Table 4). Modelling efficiencies greater than 0.6 are obtained for carbon concentrations. The $E F$ for $\Delta^{14} \mathrm{C}$ is 0.87 for the grassland plot in Mons, and those for $\delta^{13} \mathrm{C}$ exceed 0.80 for the grassland in Mons and the Boigneville plot (Table 6). The EF values show that the model is valid for the modelling of organic carbon depth distribution.

In detail, the simulation of $\mathrm{C},{ }^{13} \mathrm{C}$ and ${ }^{14} \mathrm{C}$ is excellent between 30 and $70 \mathrm{~cm}$ in all soils (Figs. 8 and 9). Below this depth, the model tends to systematically underestimate the organic $\mathrm{C}$ 
concentrations and $\delta^{13} \mathrm{C}$, but not $\Delta^{14} \mathrm{C}$. We can therefore conclude that the hypothesis of constant decay rates (not depth-dependent) down to $70 \mathrm{~cm}$ is consistent with the observed profiles. Underestimation of carbon content below $70 \mathrm{~cm}$ can be explained by i) an underestimation of the deep root input by the exponential rooting function; ii) an improper approximation of the continuum of decay rates by discrete pools (Table 4), which is intrinsic to the RothC model and neglects carbon intermediate between HUM (100 yrs) and IOM (2000 yrs); iii) an overestimation of the decay rate or an underestimation of the initial IOM; or iv) an underestimation of the advective movement in deep layers. Further analysis is needed to distinguish among these different hypotheses,.

Furthermore, the agreement between the simulation of the carbon and the $0-2 \mu \mathrm{m}$ particles corroborates our vertical transfer model. Indeed, it illustrates the link between the carbon content and the 0-2 $\mu \mathrm{m}$ fraction, as most of the organic carbon content is contained in the $0-2$ $\mu \mathrm{m}$ fraction (Supplementary Data file).

\subsection{Diffusion coefficient as an indicator of the bioturbation rate}

The diffusion coefficient rapidly decreases with depth (Fig. 3). Diffusion coefficients are classically used in the literature to approximate bioturbation (Wilkinson et al., 2009; Jarvis et al., 2010). To compare the modelled diffusion obtained for the pasture plot to bioturbation data based on biological indicators provided in the literature, we evaluated the mean bioturbation rates for the upper $30 \mathrm{~cm}$ layer of the soil, which corresponds to the depth classically considered in ecological studies. To this end, we used the method described in Jarvis et al. (2010) and Jagercikova et al. (2014a), taking into account the mean diffusion for the upper $30 \mathrm{~cm}$ of the pasture plot, the soil bulk density $\left(1.32 \mathrm{~g} \cdot \mathrm{cm}^{-3}\right)$ and the earthworm length $(8 \mathrm{~cm}$ at the grassland site). The mean diffusion coefficient ranges from 1.4 to $2.9 \mathrm{~cm}^{2} \cdot \mathrm{yr}^{-1}$ for the pasture plot, and the calculated bioturbation rates vary from 693 to $1,473 \mathrm{t} \cdot \mathrm{ha}^{-1} \cdot \mathrm{yr}^{-1}$. When considering vertical 
movement, ecological studies estimate that the bioturbation induced by anecic worms dominates in temperate climates (Gobat at al. 2004; Persson et al. 2007). According to Bouche (1981), anecic species consume approximately 200 times their biomass of dry matter per year, thereby generating bioturbation rates ranging from 6 to $400 \mathrm{t} \cdot \mathrm{ha}^{-1} \cdot \mathrm{yr}^{-1}$ for grasslands (Jagercikova et al. 2014a). The estimation provided by the multi-tracer approach is thus significantly higher than those based on anecic worm biomass. In both cases, the estimated ranges are very wide, and significant uncertainties remain regarding the quantification of bioturbation. Our estimation based on a diffusion coefficient includes i) all processes of pedoturbation, not just earthworm activity, including the processes associated with rooting (fall of soil in dead root pores) or swelling and shrinking; ii) some solute transport. Accordingly, this estimation provides a maximized value of (bio)turbation in soils. The discrepancies observed between the two approaches must be further investigated and better understood to improve the estimation of bioturbation in soils.

3.4 Application of transfer coefficients to modelling of the vertical distributions of the $0-2 \mu \mathrm{m}$ particle-size fractions

The determined transfer coefficients (Table 5) are applied to the vertical distribution of the $0-2 \mu \mathrm{m}$ fraction in the uppermost metre of the soil profiles. Model efficiencies range from 0.88 to 0.97 (Table 6), according to the site. The simulations reproduce, within the range of measurement uncertainties, i) the upper and lower $0-2 \mu \mathrm{m}$ concentrations, except at the Feucherolles site, where the simulated $0-2 \mu \mathrm{m}$ concentrations in the upper part of the profile are higher than the measured values, and ii) the depth of the inflexion points in the $0-2 \mu \mathrm{m}$ concentrations within a precision of $5 \mathrm{~cm}(10 \mathrm{~cm}$ for cropland at Boigneville) (Fig. 10). Nevertheless, concentrations measured in the $0-2 \mu \mathrm{m}$ bulge are underestimated by the model (Fig. 10). The model underestimates the $0-2 \mu \mathrm{m}$ particles accumulation in the bulge by $76 \%$ at 
the grassland plot. This result is, however, obtained i) for an initial 0-2 $\mu \mathrm{m}$ particle content of $24 \%$ in the loess parent material, which is higher than the contents generally found in loess (Table 7); ii) considering that the advection-diffusion coefficient represents particle-bound transfer only, although the occurrence of some transfer under soluble form may not be entirely excluded. The model underestimation of the $0-2 \mu \mathrm{m}$ particles accumulation in the bulge is thus minimal. Other processes, such as clay neo-formation, probably contributed to the formation of this horizon. In addition, long-term erosion is not considered in our modelling approach, while soil truncation at the surface due to human activity from the Neolithic times cannot be ruled out.

Finally, the temporal evolution over the last $15 \mathrm{kyr}$ of the $0-2 \mu \mathrm{m}$ fraction distribution is reconstructed for the grassland plot (Fig. 11 and video in Supplementary Data). After 30 years, a 0-2 $\mu \mathrm{m}$ fraction bulge is formed. With time, this bulge migrates deeper and widens due to the accumulation of $0-2 \mu \mathrm{m}$ particles and the occurrence of diffusive processes. It reaches the dimension and position of the present-day Bt-horizon after approximately $5 \mathrm{kyr}$. Then its migration almost stagnates as it reaches a depth range where the advection velocity is low, and the $0-2 \mu \mathrm{m}$ fraction distribution does not significantly change after $9 \mathrm{kyr}$ of simulation (i.e., over the last $6 \mathrm{kyr}$ ). This simulated age of the Bt-horizon agrees with the estimated ${ }^{14} \mathrm{C}$ age of greater than $3.4 \mathrm{kyr}$. The $0-2 \mu \mathrm{m}$ depth distribution does not significantly evolve over the last $5 \mathrm{kyr}$ because both diffusion and advection processes are still ongoing and compensate for each other. The system can be considered as having reached a steady state. Nevertheless, in this model, the decarbonation and $\mathrm{Ca}^{2+}$ desaturation of the parent loess material are not considered. These processes may take several thousands of years to occur (Finke and Hutson 2008; Quénard et al. 2011) and may impede 0-2 $\mu$ m particle translocation (Jamagne 1973; Quénard et al. 2011). Independent simulation with SoilGen (Finke 2012) at this site with the same parent material hypothesis led to estimates of $5 \mathrm{kyr}$ for decarbonation of $0.5 \mathrm{~m}$ of loess and $6 \mathrm{kyr}$ for 
decarbonation of $1 \mathrm{~m}$ of loess. Because the steady state persists over at least $6 \mathrm{kyr}$ in the simulation, the estimated duration for decarbonation remains relevant to the duration required to form the Bt-horizon generated by our simulation. At last, the steady state is disturbed by the introduction of agriculture. Indeed, a noticeable change occurs in the 0-20 cm layer after the introduction of tillage practices, considered to have occurred between 1700 and 1939 AD for this plot.

\section{Conclusions}

Redistribution of ${ }^{137} \mathrm{Cs}$, meteoric ${ }^{10} \mathrm{Be}$, and ${ }^{210} \mathrm{~Pb}_{(\mathrm{xs})}$ with depth in the studied soils is simulated using a diffusion-advection equation with a single set of vertically variable coefficients. The resulting depth evolutions of the two coefficients are consistent with the soil characteristics controlling particle mobilization and/or transfer in soils under both particulate and soluble forms. The mean advection velocities vary to depths between 0.03 and $0.09 \mathrm{~cm} . \mathrm{yr}^{-}$ ${ }^{1}$. To be fully comprehensive, additional processes such as lateral mixing (between macropores and the soil matrix), compaction, erosion and alteration should be added to the current model as well as explicit consideration of both solute and particulate transfers. These improvements might be achieved by including new datasets from other disciplines (past erosion rates, parent material compositions and atmospheric isotopic fluxes).

Based on the obtained advection-diffusion coefficients, we satisfactorily model the organic carbon, $\delta^{13} \mathrm{C}$ and ${ }^{14} \mathrm{C}$ depth distributions in the studied Luvisols. The model, however, slightly underestimates the carbon content below $70 \mathrm{~cm}$, likely due to the organic carbon representation, which is split into the 5 RothC pools. This independent verification confirms the validity of the defined depth-dependent advection velocity and diffusion parameters.

The surface diffusion coefficient is equal to $3.2 \pm 1.0 \mathrm{~cm}^{2} \mathrm{yr}^{-1}$ at the Mons grassland plot. When used as a proxy for bioturbation, the modelled diffusion term leads to significantly higher 
estimates than those found in the literature and those derived from anecic and endogeic worm biomass data under similar climatic conditions. Further studies should therefore be performed to better understand the processes involved and to reconcile both approaches. The fact that carbon profiles in the top $70 \mathrm{~cm}$ can be reproduced by the same solid matter transport parameters as ${ }^{137} \mathrm{Cs}$ also supports the suggestion that carbon concentrations could be used with

${ }^{137} \mathrm{Cs}$ to constrain the bioturbation intensity and depth in these environments. This finding is in line with the common observations of field soil scientists, who diagnose the intensity of bioturbation through the observation of the carbon profile.

Regarding clay translocation, we conclude that i) it is possible to simulate the formation of a Bt-horizon at the appropriate depth by restricting modelling to vertical solid transfers and ii) the $0-2 \mu \mathrm{m}$ fraction bulge is rapidly formed (within a few decades after the beginning of the simulation), demonstrating that clay translocation is a rapid process. We also highlight that vertical solid matter transfer explains a maximum of $24 \%$ of the $0-2 \mu \mathrm{m}$ accumulation in the Bt-horizon, the rest being due to other processes, such as in situ weathering of primary minerals and clay neo-formation.

In conclusion, this study presents a model capable of simultaneously reproducing the isotopic profiles of several tracers and simulating the organic carbon distribution down to a depth of $70 \mathrm{~cm}$ and the $0-2 \mu \mathrm{m}$ fraction translocation. We also coupled the $0-2 \mu \mathrm{m}$ fraction and the organic carbon depth evolution; such a coupling could improve long-term organic carbon modelling.

Acknowledgements This research was conducted in the framework of the Agriped project (ANR-10-BLANC-605) supported by the French National Research Agency (ANR). M. Jagercikova received a $\mathrm{PhD}$ grant from the French National Institute for Agricultural Research (INRA). The authors are grateful to Dr. Frédéric Golay, Dr. Cédric Galusinski and Dr. Gloria 
Faccanoni for their suggestions regarding numerical modelling; to Patrick Signoret for carbon stable isotope analyses; to Dr. Bruno Mary, Dr. David Montagne and Nicolas Brunet for providing soil bulk density data; to the Agriped team for its contribution to sampling; and to the INRA of Mons-en-Chaussée, Grignon and Arvalis for providing access to their long-term experimental sites and the associated data. M. Arnold, G. Aumaître and K. Keddadouche are thanked for their valuable assistance during ${ }^{10} \mathrm{Be}$ measurement at the ASTER AMS national facility (CEREGE, Aix-en-Provence), which is supported by the INSU/CNRS, the ANR through the "Projets thématiques d'excellence" programme for the "Equipements d'excellence" ASTER-CEREGE action (ANR-10-EQPX-24-1), IRD and the CEA. This is an LSCE contribution \#2016-XXX.

\section{References}

Ahrens B, Reichstein M, Borken, W, Muhr J, Trumbore SE and Wortzler T (2014) Bayesian calibration of a soil organic carbon model using $\Delta 14 \mathrm{C}$ measurements of soil organic carbon and heterotrophic respiration as joint constraints. Biogeosciences 11:2147-2168

Al-Masri MS (2006) Vertical distribution and inventories of Cs-137 in the Syrian Soils of the Eastern Mediterranean region. J Environ Radioactiv 86(2):187-198

Antoine P, Catt J, Lautridou JP, Somm’e J (2003) The loess and coversands of northern France and southern England. J Quaternary Sci 18(3-4):309-318

Antoine P, Rousseau DD, Lautridou JP, Hatt'e C (1999) Last interglacial- glacial climatic cycle in loess-palaeosol successions of north-western France. Boreas 28:551-563

Balesdent J, Balabane M (1992) Maize root-derived soil organic carbon estimated by natural 13C abundance. Soil Biol Biochem 24:97-101

Bettis EA, Muhs DR, Roberts HM, Wintle AG (2003) Last Glacial loess in the conterminous USA. Quaternary Science Reviews 22(18-19):1907-1946 
Bockheim J, Gennadiyev A (2000) The role of soil-forming processes in the def- inition of taxa in Soil Taxonomy and the World Soil Reference Base. Geoderma 95(1-2):53-72

Bouché MB (1981) Contribution des lombriciens aux migrations d'éléments dans les sols tempérés, vol. 303. Colloques Internationaux du Centre National de la Recherche Scientifique pp 145-153

Bundt M, Albrecht A, Froidevaux P, Blaser P, Flühler H (2000) Impact of preferential flow on radionuclide distribution in soil. Environ Sci Technol 34(18):3895-3899

Cambray RS, Playford K, Lewis G, Carpenter R (1989) Radioactive fallout in air and rain: results to the end of 1988. Environmental and Medical Sciences Division, United Kingdom Atomic Energy Authority

Campforts B, Vanacker V, Vanderborght J, Baken S, Smolders E, Govers G (2016) Simulating the mobility of meteoric ${ }^{10} \mathrm{Be}$ in the landscape through acoupled soil-hillslope model (Be2D). Earth Plan Sci Lett 439:143-157

Coleman K, Jenkinson D (1999) RothC-26.3. A model for the turnover of carbon in soils. Herts, Rothamsted Research, Harpenden, Hertfordshire, UK

Coplen T, Brand W, Gehre M, Gröning M, Meijer H, Toman B, Verkouteren R (2006) After two decades a second anchor for the VPDB $\delta^{13} \mathrm{C}$ scale. Rapid communications in mass spectrometry: RCM 20(21):3165

Cottereau E, Arnold M, Moreau C, Baqué D, Bavay D, Caffy I, Comby C, Dumoulin J, Hain S, Perron M, Salomon J, Setti V (2007) Artemis, the new ${ }^{14}$ C AMS at LMC14 in Saclay, France. Radiocarbon 49(2):291-299

Cremers A, Elsen A, Depreter P, Maes A (1988) Quantitaive-analysis of radiocesium retention in soils. Nature 335(6187):247-249

Davis BAS, Brewer S, Stenvenson AC, Guiot J, Data Contributors (2003) The temperature of Europe during the Holocene reconstructed from pollen data. Quaternary Sci Rev 
496

497

498

499

500

501

502

503

504

505

506

507

508

509

510

511

512

513

514

515

516

517

518

519

Dörr H, Münnich K (1989) Downward movement of soil organic-matter and its influence on trace-element transport (Pb-210, Cs-137) in the soil. Radiocarbon 31(3):655-663, 13th International Radiocarbon conf, Dubrovnik, Yugoslavia, June 20-25, 1988

Finke PA (2012) Modeling the genesis of luvisols as a function of topographic position in loess parent material. Quaternary Int 265:3-17

Finke PA, Hutson JL (2008) Modelling soil genesis in calcareous loess. Geoderma 145(3):462479

Francey R, Allison C, Etheridge D, Trudinger C, Enting I, Leuenberger M, Langenfelds R, Michel E, Steele L (1999) A 1000-year high precision record of $\delta^{13} \mathrm{C}$ in atmospheric $\mathrm{CO}_{2}$. Tellus B 51(2):170-193

Gobat JM, Aragno M, Matthey W (2004) The living soil: fundamentals of soil science and soil biology. Science Publishers

Graly J A, Bierman P R, Reusser L J, Pavich M J (2010) Meteoric Be-10 in soil profiles - A global meta-analysis. Geochimica et Cosmochimica Acta 74(23):6814-6829

He Q, Walling D (1997) The distribution of fallout Cs-137 and Pb-210 in undisturbed and cultivated soils. Appl Radiat Isotopes 48(5):677-690

Hua Q, Barbetti M, Rakowski A Z (2013) Atmospheric radiocarbon for the period 1950-2010. Radiocarbon 55(4):2059-2072

Jacobsen O H, Moldrup P, Larsen C, Konnerup L, Petersen LW (1997) Particle transport in macropores of undisturbed soil columns. J Hydrol 196(1- 4):185-203

Jagercikova M, Evrard O, Balesdent J, Lefèvre I, Cornu S (2014a) Modeling the migration of fallout radionuclides to quantify the contemporary transfer of fine particles in luvisol profiles under different land uses and farming practices. Soil Till Res 140:82-97

Jagercikova M, Cornu S, Le Bas C, Evrard O (2014b) Vertical distributions of ${ }^{137}$ Cs in soils: a 
521

522

523

Jagercikova M, Cornu S, Bourlès D, Antoine P, Mayor M, Guillou V (2015) Understanding long-term soil processes using meteoric ${ }^{10} \mathrm{Be}$ : a first attempt on loessic deposits. Quaternary Geochronology 27:11-21

Jamagne M (1973) Contribution à l'étude pédologique des formations loessiques du Nord de la France. Ph.D., Thèse d'état de la faculté des sciences agronomiques, Gembloux Belgique

Jamagne M, Pedro G (1981) Les phénomènes de migration et d'accumulation de particules au cours de la pédogenèse sur les formations limoneuses du Nord de la France. Essai de caractérisation du processus de "lessivage". Comptes Rendus de l'Académie des sciences 292:1329-1332

Jarvis N J, Taylor A, Larsbo M, Etana A, Rosen K (2010) Modelling the effects of bioturbation on the re-distribution of ${ }^{137} \mathrm{Cs}$ in an undisturbed grassland soil. Eur J Soil Sci 61(1):2434

Jenkinson, D, Coleman K (2008) The turnover of organic carbon in subsoils. Part 2. Modelling carbon turnover. Eur J Soil Sci 59(2):400-413

Jenkinson DS, Rayner JH (1977) The turnover of soil organic matter in some of the Rothamsted classical experiments. Soil Sci 123(5):298-305

Joret G, Malterre H (1947) Les sols du Santerre et du Vermandois. In: Extrait Annales Agronomiques. Dunod, Paris

Kaste JM, Heimsath AM, Bostick BC (2007) Short-term soil mixing quantified with fallout radionuclides. Geology 35(3):243-246

Korschinek G, Bergmaier A, Faestermann T, Gerstmann UC, Knie K, Rugel G, Wallner A, Dillmann I, Dollinger G, Lierse Von Gostomski Ch, Kossert K, Maiti M, Poutivtsev M, Remmert A (2010) A new value for the half-life of 10Be by heavy-ion elastic recoil 
detection and liquid scintillation counting. Nucl Instrum 268:187-191

Koven CD, Riley WJ, Subin ZM, Tang JY, Torn MS, Collins WD, Bonan GB, Lawrence D M Swenson SC (2013) The effect of vertically resolved soil biogeochemistry and alternate soil C and N models on C dynamics of CLM4. Biogeosciences 10:7109-7131

Lal D, Peters B (1967) Cosmic ray produced radioactivity on the Earth. In: Kosmische Strahlung II/Cosmic Rays II. Springer, pp 551e612

Loague K, Green RE (1991) Statistical and graphical methods for evaluating solute transport models: overview and application. Journal Contam Hydrol 7(1):51-73

Majdalani S, Michel E, Di Pietro L, Angulo-Jaramillo R, Rousseau M (2007) Mobilization and preferential transport of soil particles during infiltration: A corescale modeling approach. Water Resour Res 43(5): doi: 10.1029/2006WR005057

Matisoff G, Ketterer ME, Rosen K, Mietelski JW, Vitko LF, Persson H, Lokas E (2011) Downward migration of Chernobyl-derived radionuclides in soils in Poland and Sweden. Applied Geochem 26(1):105-115

Milton GM, Kramer SJ, Watson WL, Kotzer TG (2001) Qualitative estimates of soil disturbance in the vicinity of CANDUS stations, utilizing measurements of $137 \mathrm{Cs}$ and $210 \mathrm{~Pb}$ in soil cores. J Environ Radioactiv 55(2):195-205

Pavich MJ, Brown L, Klein J, Middleton R (1984) Be-10 accumulation in a soil chronosequence. Earth Planet Sci Lett 68(2):198e204

Pavich MJ, Brown L, Harden J, Klein J, Middleton R (1986) Be-10 distribution in soils from Merced River terraces, California. Geochimica Cosmochimica Acta 50(8):1727e1735

Pécsi M (1990) Loess is not just the accumulation of dust. Quaternary International 7:1-21

Persson T, Lenoir L, Taylor A (2007) Bioturbation in different ecosystems at Forsmark and Oskarhamn. SKB Rapport R-06-123. Stockholm Sweden

Quénard L, Samouëlian A, Laroche B, Cornu S 2011 Lessivage as a major process of soil 
Reimer PJ, Baillie MG, Bard E, Bayliss A, Beck JW, Blackwell PG, Ramsey CB, Buck CE, Burr GS, Edwards RL, Friedrich M, Grootes PM, Guilderson TP, Hajdas I, Heaton TJ, Hogg AG, Hughen KA, Kaiser KF, Kromer B, McCormac FG, Manning SW, Reimer RW, Richards DA, Southon JR, Talamo S, Turney CSM, Van der Pflicht J, Weyhenmeyer CE (2009) Intcal09 and marine09 radiocarbon age calibration curves, 050,000 years cal BP. Radiocarbon 51:1111-1150

Roussel-Debel S, Renaud P, Metivier J-M (2007) ${ }^{137}$ Cs in French soils: Deposition patterns and 15-year evolution. Science Total Environ 374(2):388-398

Salvador-Blanes S, Minasny B, McBratney A (2007) Modelling long-term in situ soil profile evolution: application to the genesis of soil profiles containing stone layers. Eur J Soil Sci 58(6):1535-1548

Samouelian A, Cornu S (2008) Modelling the formation and evolution of soils, a synthesis. Geoderma 145(3-4):401-409

Sawhne B (1972) Selective sorption and fixation of cations by clay minerals: a review. Clays Clay Miner 20:93-100

Schimmack W, Márquez FF (2006) Migration of fallout radiocaesium in a grassland soil from 1986 to 2001: Part II: Evaluation of the activity-depth profiles by transport models. Sci Total Environ 368(2):863-874

Schmitt J, Schneider R, Elsig J, Leuenberger D, Lourantou A, Chappellaz J, Köhler P, Joos F, Stocker T F, Leuenberger M, Lourantou A, Chappelaz J, Köhler P, Joos F, Stocker TF, Leuenberger M, Fischer $\mathrm{H}$ (2012) Carbon isotope constraints on the deglacial $\mathrm{CO}_{2}$ rise from ice cores. Science 336(6082):711-714

Schuller P, Ellies A, Kirchner G (1997) Vertical migration of fallout Cs-137 in agricultural soils from Southern Chile. Sci Total Environ 193(3):197-205 
Sterckeman T, Douay F, Baize D, Fourrier H, Proix N, Schvartz C, Carignan J (2006) Trace element distributions in soils developed in loess deposits from northern France. Eur $\mathbf{J}$ Soil Sci 57(3):392-410

Stuiver M, Polach HA (1977) Discussion; reporting of C-14 data. Radiocarbon 19(3):355-363

Swinnen J, Van Veen JA, Merckx R (1994) ${ }^{14}$ C pulse-labelling of field-frown spring wheat: an evaluation of its use in rhizosphere carbon budget estimation. Soil Biol Biochem 26:161-170

Takahashi Y, Minai Y, Ambe S, Makide Y, Ambe F (1999) Comparison of adsorption behavior of multiple inorganic ions on kaolinite and silica in the presence of humic acid using the multitracer technique. Geochimica et Cosmochimica Acta 63(6):815-836

Tamura T, Jacobs D (1960) Structural implications in Cesium sorption. Health Physics 2(4):391-398

Ullrich A, Volk M (2009) Application of the soil and water assessment tool (SWAT) to predict the impact of alternative management practices on water quality and quantity. Agric. Water Manag 96(8):1207-1217

Verbruggen C, Denys L, Kiden P (1996) Belgium. In: Berglund BE, Birks HJB, RalskaJasiewiczowa M, Wright HE (eds) Palaeoecological Events during the Last 15000 Years. Regional Syntheses of Palaeoecological Studies of Lakes and Mires in Europe. Wiley, Chistester

Warembourg FR, Paul EA (1977) Seasonal transfers of assimilated 14C in grassland: Plant production and turnover, soil and plant respiration. Soil Biol Biochem 9:295-301

White J, Vaughn B (2011) University of Colorado, Institute of Arctic and Alpine Research (INSTAAR), Stable Isotopic Composition of Atmospheric Carbon Dioxide $\left({ }^{13} \mathrm{C}\right.$ and ${ }^{18}$ O) from the NOAA ESRL Carbon Cycle Cooperative Global Air Sampling Network, 1990-2012, Version: 2013-04-05. URL ftp://ftp.cmdl.noaa.gov/ccg/co2c13/flask/event/ 
620 Wilkinson MT, Richards PJ, Humphreys GS (2009) Breaking ground: Pedological, geological, and ecological implications of soil bioturbation. Earth-Sci Rev 97(1-4):257-272

622 Willenbring JK, von Blanckenburg F (2010) Meteoric cosmogenic Beryllium-10 adsorbed to 623 river sediment and soil: applications for Earth-surface dynamics. Earth-Sci Rev 98(1e2):105e122

625 You CF, Lee T, Li YH (1989) The partition of Be between soil and water. Chem Geol 626 77(2): 105-118

627 
Figure 1: Location of the study sites in Northern France (red asterix - campaign in 2011; open asterix -

Figure 2: Measured depth distributions of a- the $0-2 \mu \mathrm{m}$ fraction, b- organic carbon content and $\mathrm{c}$ - the $\mathrm{pH}_{\mathrm{H} 2 \mathrm{O}}$ for all sampled soils. CT stands for cultivation

Figure 3: Evolution of a- advection velocity and b- diffusion with soil depth, as determined by the multi-isotopic modelling performed on ${ }^{137} \mathrm{Cs}$ and meteoric ${ }^{10} \mathrm{Be}$ data. $\mathrm{CT}$ stands for cultivation.

638

Figure 4: Measured (green) and simulated (blue curves) vertical isotopic distributions at Mons grassland: a- ${ }^{137} \mathrm{Cs}$; b- meteoric ${ }^{10} \mathrm{Be}$; and c- ${ }^{210} \mathrm{~Pb}(\mathrm{xs})$

641

Figure 5: Measured (green) and simulated (blue curves) vertical distributions at Boigneville cultivation: a- ${ }^{137} \mathrm{Cs}$; b- meteoric ${ }^{10} \mathrm{Be}$. $\mathrm{Pb}-210$ (xs) measurements were below the detection limit

644

Figure 6: Measured (green) and simulated (blue curves) vertical distributions at Mons cultivation: a- ${ }^{137} \mathrm{Cs}$; bmeteoric ${ }^{10} \mathrm{Be}$. $\mathrm{Pb}-210$ (xs) measurements were below the detection limit

Figure 7: Measured (green) and simulated (blue curves) vertical distributions at Feucherolles cultivation: a-

Figure 8: Measured (green) and simulated (blue curves) vertical isotopic distributions at Mons of a- organic carbon concentrations and RothC compartments (RPM for resistant plant matter, BIO for decomposers biomass, HUM for stabilized organic matter and IOM for almost inert organic matter), with the blue curve representing the sum of all compartments; b- $\delta^{13} \mathrm{C}$ and c- $\Delta^{14} \mathrm{C}$ for the grassland plot; and d- organic carbon concentrations and RothC compartments, with blue curve representing the sum of all compartments for the cultivation plot

Figure 9: Measured (green) and simulated (blue curves) vertical distributions of a- organic carbon concentrations and RothC compartments (RPM for resistant plant matter, BIO for decomposers biomass, HUM for stabilized organic matter and IOM for almost inert organic matter), with the blue curve representing the sum of all compartments and b- $\delta^{13} \mathrm{C}$ for Boigneville cultivation; c- organic carbon concentrations and RothC compartments for Feucherolles cultivation, with blue curve representing the sum of all compartments

Figure 10: Measured (green) and simulated (blue curves) of the 0-2 $\mu \mathrm{m}$ fraction vertical distributions considering the transfer coefficient reported in Table 5: a and b- Mons grassland and cultivation, respectively; c- Feucherolles cultivation; and d- Boigneville cultivation 
669 year 14,939

670

671 
Table 1: Parameters used when modelling the studied isotopes (initial concentrations, input histories, and fraction of the inherited concentration subjected to advection).

\begin{tabular}{|c|c|c|c|}
\hline Isotope and $0-2 \mu \mathrm{m}$ & Input history reconstruction & Initial concentration or composition & $\begin{array}{c}\text { Fraction of the inherited } \\
\text { concentration subjected to } \\
\text { advection }\end{array}$ \\
\hline${ }^{137} \mathrm{Cs}$ & $\begin{array}{l}\text { Nuclear weapon tests (Cambray et al., } \\
\text { 1989) and the Chernobyl accident in } 1986 \\
\text { (Roussel-Debel et al., 2007) }\end{array}$ & None & None \\
\hline${ }^{210} \mathrm{~Pb}(\mathrm{xs})$ & $93 \pm 8 \mathrm{~Bq} \mathrm{~m}^{-2} \mathrm{yr}^{-1}$ (Jagercikova et al., 2014) & None & None \\
\hline Carbon & $\begin{array}{l}\text { After Davis et al., 2003, Verbruggen et al. } \\
\text { (1996), Meteo France data and site's data }\end{array}$ & $0.005 \mathrm{~g} \mathrm{~g}^{-1}$ & \\
\hline$\delta^{13} \mathrm{C}$ & $\begin{array}{l}\text { Francey et al. (1999); White and Vaughn } \\
\text { (2011); Schmitt et al. (2012) }\end{array}$ & $\begin{array}{l}-23 \% \text { (Mons and Feucherolles) } \\
\text { and } 24 \% \text { (Boigneville) }\end{array}$ & None \\
\hline$\Delta^{14} \mathrm{C}$ & $\begin{array}{l}\text { Natural flux (Reimer et al., 2009) and } \\
\text { nuclear weapon tests (Hua et al., 2013) }\end{array}$ & 275.7\%o (Reimer et al., 2009) & \\
\hline Meteoric ${ }^{10} \mathrm{Be}$ & $\begin{array}{l}\text { Constant flux of } 1.15 \times 10^{6} \text { atoms } \mathrm{cm}^{-2} \mathrm{yr}^{-1} \\
\text { (Jagercikova et al., 2015) }\end{array}$ & $\begin{array}{l}3.4 \times 10^{8} \text { atoms } \mathrm{cm}^{-3} \text { (Mons); } \\
4.2 \times 10^{8} \text { atoms } \mathrm{cm}^{-3} \text { (Feucherolles); } \\
7.6 \times 10^{8} \text { atoms cm} \\
\text { (Jagercikova etal., } 2015 \text { ) }\end{array}$ & $20 \%$ \\
\hline $0-2 \mu \mathrm{m}$ & None & $\begin{array}{l}240 \mathrm{~g} \mathrm{~kg}^{-1} \text { (Mons and Feucherolles) } \\
280 \mathrm{~g} \mathrm{~kg}^{-1} \text { (Boigneville) }\end{array}$ & $20 \%$ \\
\hline
\end{tabular}


Table 2: General descriptions of the study sites.

\begin{tabular}{|c|c|c|c|}
\hline Site & Mons & Feucherolles & Boigneville \\
\hline Experiment name & $\begin{array}{l}\text { Essay system - ORE-ACBB } \\
\text { Mons }\end{array}$ & ORE-PRO $^{\mathrm{b}}$-Qualiagro & Wheat monoculture \\
\hline Managing institution & INRA & INRA & Arvalis (Plant institute) \\
\hline Geographic coordinates & $49^{\circ} 52^{\prime} 01^{\prime \prime} \mathrm{N}-3^{\circ} 01^{\prime} 53^{\prime \prime} \mathrm{E}$ & $48^{\circ} 53$ '49’'N - 1'58'19’'E & $2^{\circ} 22^{\prime} 58^{\prime \prime} \mathrm{E}-48^{\circ} 19^{\prime} 30^{\prime \prime} \mathrm{N}$ \\
\hline Elevation & $88 \mathrm{~m}$ & $120 \mathrm{~m}$ & $116 \mathrm{~m}$ \\
\hline Mean annual rainfall & $680 \mathrm{~mm}$ & $660 \mathrm{~mm}$ & $630 \mathrm{~mm}$ \\
\hline $\begin{array}{l}\text { Mean annual } \\
\text { temperature }\end{array}$ & $11^{\circ} \mathrm{C}$ & $11.2^{\circ} \mathrm{C}$ & $10.4^{\circ} \mathrm{C}$ \\
\hline Considered land uses & $\begin{array}{l}\text { Cultivation } \\
\text { Grassland (since 1939) }\end{array}$ & Cultivation & Cultivation \\
\hline Crop rotation & $\begin{array}{l}\text { Wheat - corn - sugar beet } \\
\text { rotation }\end{array}$ & Corn - wheat rotation & Wheat (continuous) \\
\hline Liming & $\begin{array}{l}\text { Not since } 1986 \text { for } \\
\text { cultivation and } 1939 \text { for } \\
\text { pasture }\end{array}$ & Not since 1998 & Not since 1970 \\
\hline Sampling date & March 2011 & April 2011 & March 2012 \\
\hline
\end{tabular}


Table 3: Synthetic soil description of the different plots and sites.

\begin{tabular}{|c|c|c|c|c|c|c|c|c|}
\hline \multirow{2}{*}{ Sites } & \multirow{2}{*}{ Plots } & \multicolumn{7}{|c|}{ Horizon } \\
\hline & & $\mathbf{A}$ & $\mathbf{E}$ & Degraded Bt & Bt & $\mathbf{C} / \mathbf{B t}$ & $\mathbf{C}$ & II \\
\hline Mons & $\begin{array}{l}\text { Cultivation } \\
\text { Grassland }^{b}\end{array}$ & $\begin{array}{l}\text { Silt-loam, } 10 \text { YR } 4 / 4^{\mathrm{a}} \text { : } \\
0-28 \mathrm{~cm} \text { : tillage horizon, } \\
\text { crumbly, no earthworms. } \\
28-38 \mathrm{~cm} \text { : base of the ancient } \\
\text { tillage, polyhedral, few } \\
\text { earthworms. } \\
\text { Richer in organic matter and ear } \\
\text { activity, exhibiting darker colou } \\
\text { and frequent earthworm casts }\end{array}$ & $\begin{array}{l}\text { None } \\
\text { hworm } \\
\text { s (10 YR 3/2) }\end{array}$ & None & $\begin{array}{l}38-130 \mathrm{~cm} \text { : silty } \\
\text { clay-loam, } \\
\text { prismatic, } \\
10 Y R 4 / 4^{\text {a }} \text { with } \\
7.5 \mathrm{YR} 4 / 4 \text { coatings, } \\
\text { few earthworms. }\end{array}$ & $\begin{array}{l}130-150 \mathrm{~cm} \text { : silt- } \\
\text { loam, } \\
\text { continuous, } \\
\text { 10YR5/6, few } \\
\text { earthworms. }\end{array}$ & $\begin{array}{l}>150 \mathrm{~cm} \text { : same } \\
\text { characteristics as } \\
\mathrm{C} / \mathrm{Bt} \text {, no } \\
\text { earthworms. }\end{array}$ & None \\
\hline Feucherolles & Cultivation & $\begin{array}{l}0-25(27) \mathrm{cm} \text { : tillage horizon, } \\
\text { silt loam, crumbly to } \\
\text { polyhedrous, } 10 \mathrm{YR} 4 / 4^{\mathrm{a}} \text {. } \\
25(27)-32(35) \mathrm{cm} \text { : base of the } \\
\text { former tillage, poorly } \\
\text { polyhedrous. }\end{array}$ & $\begin{array}{l}32(35)-45(50) \\
\mathrm{cm}, \text { silt loam, } \\
\text { poorly } \\
\text { polyhedrous, } \\
10 Y \text { Y } 4 / 6^{\mathrm{a}} \text {. }\end{array}$ & $\begin{array}{l}45(50)-75(80) \\
\text { cm: silty clay } \\
\text { loam, prismatic, } \\
7.5 Y R 4 / 6^{\mathrm{a}} \text { with } \\
\text { 10YR4/6 } \\
\text { tongues. }\end{array}$ & $\begin{array}{l}75(80)-95(100) \mathrm{cm}: \\
\text { silty clay loam, } \\
10 Y R 5 / 6^{\mathrm{a}} \text { with } \\
7.5 \text { YR4/6 coatings. }\end{array}$ & None & $\begin{array}{l}95(100)-160 \mathrm{~cm}: \\
\text { silt loam, } 10 \\
\text { YR5/6a, water- } \\
\text { logged at its base } \\
\text { during sampling; } \\
\text { 160-168(172) } \\
\mathrm{cm} \text { : carbonated } \\
\mathrm{Ck} \text {. }\end{array}$ & $\begin{array}{l}>168(172) \mathrm{cm} \text { : } \\
\text { clays with } \\
\text { gritstone gravels. }\end{array}$ \\
\hline Boigneville & Cultivation & $\begin{array}{l}0-20(25) \mathrm{cm} \text { : tillage horizon, } \\
\text { silt loam, crumbly, } 10 \mathrm{YR} 4 / 4^{\mathrm{a}} \text {; } \\
\text { 20(25)-35 cm, former tillage, } \\
\text { compact, more clayey, } \\
\text { 10YR3/3.5 }\end{array}$ & None & None & $\begin{array}{l}34(50)-73(80) \mathrm{cm}: \\
\text { silty clay loam to } \\
\text { silty clay, } \\
\text { prismatic, } \\
10 Y R 4 / 4^{\mathrm{a}} \text { with } \\
10 \mathrm{YR} 3 / 4 \text { coatings. }\end{array}$ & None & None $^{\mathrm{c}}$ & $\begin{array}{l}>73(80) \mathrm{cm}: \\
\text { transition to } \\
\text { another parent } \\
\text { material. }\end{array}$ \\
\hline
\end{tabular}

\footnotetext{
a According to the Munsell Soil Color Chart, 2000.

${ }^{\mathrm{b}}$ Only changes compared to the reference cropped profile at the same site are described.

${ }^{\mathrm{c}}$ A fresh loess sample could not be collected at Boigneville, where it was entirely pedogenetised.
} 
Table 4: Proportion of the organic carbon compartment $(P)$ and its decay rate $k$ used for modelling the carbon dynamics in soil. All parameters are the RothC default values from Coleman and Jenkinson (1999) except $P_{I O M}$ and $k_{I O M}$.

\begin{tabular}{|c|c|c|c|c|}
\hline Parameters & Mons Grassland & Mons $\mathrm{CT}^{\mathrm{a}}$ & Feucherolles $\mathrm{CT}^{\mathrm{a}}$ & Boigneville $\mathrm{CT}^{\mathrm{a}}$ \\
\hline$P_{D P M}$ & 0.4 & 0.59 & 0.59 & 0.59 \\
\hline$P_{R P M}$ & 0.6 & 0.41 & 0.41 & 0.41 \\
\hline$P_{B I O}$ & 0.099 for $z=0^{b}$ & 0.098 for $z=0^{b}$ & 0.093 for $z=0^{b}$ & 0.104 for $z=0^{b}$ \\
\hline$P_{H U M}$ & 0.116 for $z=0^{b}$ & 0.115 for $z=0^{b}$ & 0.110 for $z=0^{b}$ & 0.122 for $z=0^{b}$ \\
\hline$P_{I O M}$ & 0.001208 & 0.001208 & 0.001208 & 0.001208 \\
\hline $1 / k_{D P M} \mathrm{yr}$ & 0.15 & 0.13 & 0.17 & 0.21 \\
\hline $1 / k_{D P M} \mathrm{yr}$ & 5.11 & 4.50 & 5.52 & 7.03 \\
\hline $1 / k_{B I O} \mathrm{yr}$ & 2.32 & 2.04 & 2.51 & 3.20 \\
\hline $1 / k_{H U M} \mathrm{yr}$ & 76.6 & 67.5 & 82.8 & 105.5 \\
\hline $1 / k_{I O M} \mathrm{yr}$ & 2042 & 3372 & 2759 & 2812 \\
\hline
\end{tabular}

${ }^{\mathrm{a}} \mathrm{CT}$ stands for cultivation

${ }^{\mathrm{b}} P_{B I O}$ and $P_{H U M}$ are functions of $0-2 \mu \mathrm{m}$ fraction content and are thus depth-dependent: Only their surface values are reported in the table. 
Table 5: Advection and diffusion coefficients and modelling efficiencies obtained by fitting the ${ }^{137} \mathrm{Cs}$ and ${ }^{10} \mathrm{Be}$ vertical distributions.

\begin{tabular}{lcccccccc}
\hline Site & $\begin{array}{c}D_{0} \\
\mathrm{~cm}^{2} \mathrm{yr}^{-1}\end{array}$ & $\begin{array}{c}b \\
\mathrm{~cm}^{-1}\end{array}$ & $\begin{array}{c}v_{0}(z=0 \mathrm{~cm}) \\
\mathrm{cm} \mathrm{yr}\end{array}$ & $\begin{array}{c}v_{1}(z=20 \mathrm{~cm}) \\
\mathrm{cm} \mathrm{yr}^{-1}\end{array}$ & $\begin{array}{c}d \\
\mathrm{~cm}^{-1}\end{array}$ & $\begin{array}{c}E F 137 \mathrm{Cs} \\
\text { Mons }\end{array}$ \\
$\begin{array}{l}\text { Grassland } \\
\text { Cultivation }\end{array}$ & $3.22 \pm 1.02$ & $0.030 \pm 0.004$ & $0.18 \pm 0.08$ & $0.27 \pm 0.64$ & $0.090 \pm 0.004$ & 0.78 \\
Feucherolles & $0.26 \pm 0.06$ & $0.001 \pm 0.003$ & $0.03 \pm 0.15$ & $0.14 \pm 0.01$ & $0.230 \pm 0.020$ & 0.89 \\
Boigneville & $1.85 \pm 0.87$ & $0.043 \pm 0.008$ & $0.00 \pm 1.28$ & $0.12 \pm 0.02$ & $0.090 \pm 0.002$ & 0.97 & 0.99 \\
\hline
\end{tabular}


Table 6: Modelling efficiencies $(E F)$ of the 0-2 $\mu \mathrm{m}$ fraction, organic carbon and isotope depth redistributions, considering the transfer coefficients reported in Table 5.

\begin{tabular}{lcccc} 
Site & \multicolumn{4}{c}{$E F$} \\
& $0-2 \mu \mathrm{m}$ & $\mathrm{C}$ & $\delta^{13} \mathrm{C}$ & $\Delta^{14} \mathrm{C}$ \\
\hline Mons & & & & \\
Grassland & 0.95 & 0.60 & 0.89 & 0.87 \\
Cultivation & 0.91 & 0.87 & NA & NA \\
Feucherolles & 0.88 & 0.96 & NA & NA \\
Boigneville & 0.80 & 0.90 & 0.8 & NA \\
\hline
\end{tabular}


Table 7: Data compilation of worldwide $0-2 \mu \mathrm{m}$ fraction and carbonate contents in loess.

Only studies providing both loess characteristics are reported.

\begin{tabular}{llccc}
\hline Reference & Place & $\mathbf{0 - 2} \boldsymbol{\mu m}$ & $\begin{array}{c}\text { CaCO3 } \\
\mathbf{\%}\end{array}$ & $\begin{array}{c}\mathbf{0 - 2} \boldsymbol{\mu m} \% \text { after } \\
\text { carbonate } \\
\text { dissolution }\end{array}$ \\
\hline Antoine (pers. com.) & $\begin{array}{l}\text { Beugnatre (France) } \\
\text { St. Pierre les Elbeuf (NW }\end{array}$ & $15-18$ & $12-15$ & $17-21$ \\
Antoire at al. (1999) & France) & 14 & 12 & 16 \\
& Villiers Adam (Val d'Oise, & & & \\
Antoine et al. (2003) & France) & 15 & 18 & 18 \\
Bettis et al. (2003) & Columbia Plateau (USA) & 12 & 20 & 15 \\
Joret and Malterre (1947) & Mons region (France) & 14 & 12 & 16 \\
Sterckeman et al. (2006) & Nord Pas de Calais (France) & 18 & 13 & 21 \\
Pécsi (1990) & Typical loess & $5-25$ & $1-20$ & $6-31$ \\
\hline
\end{tabular}




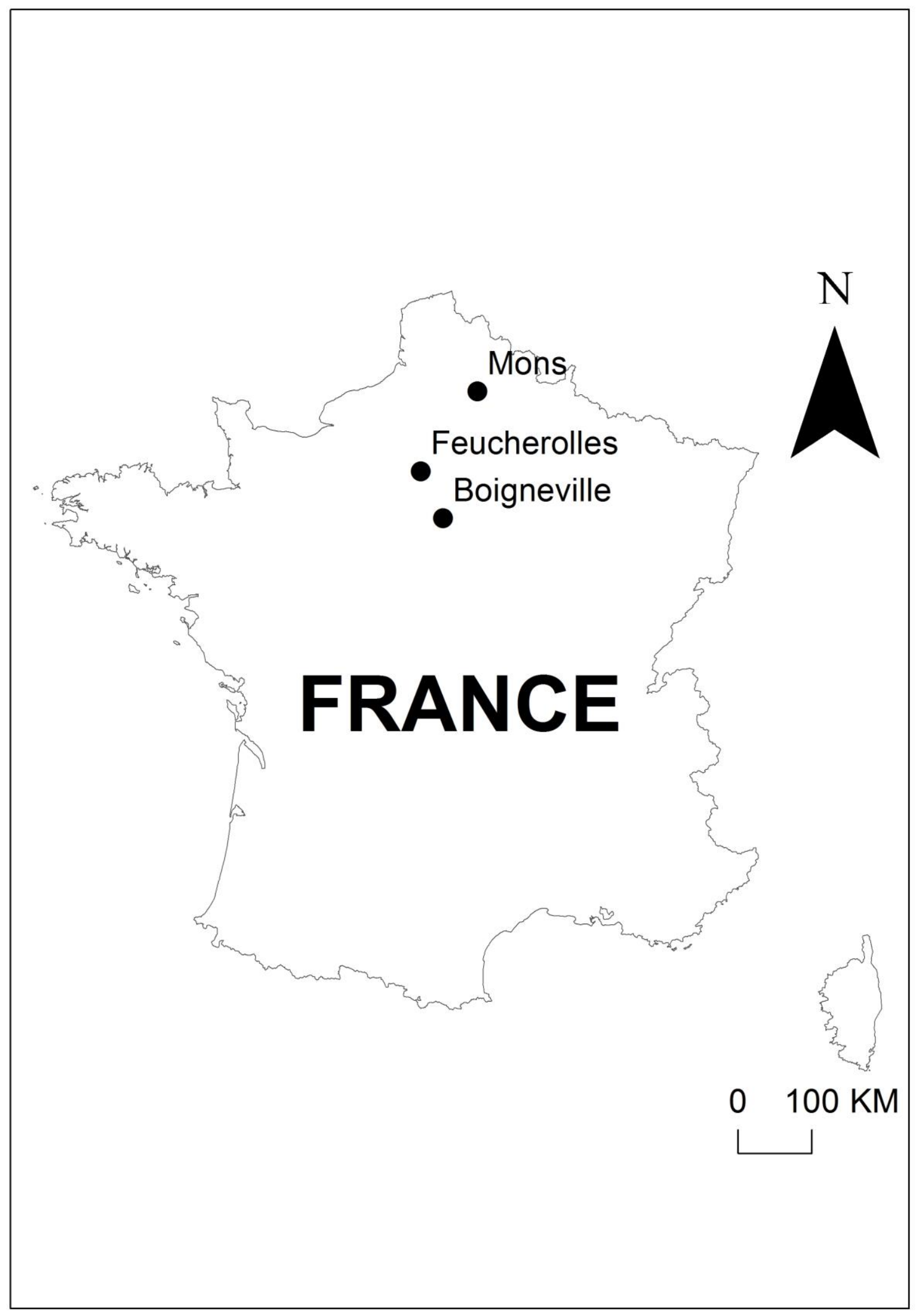




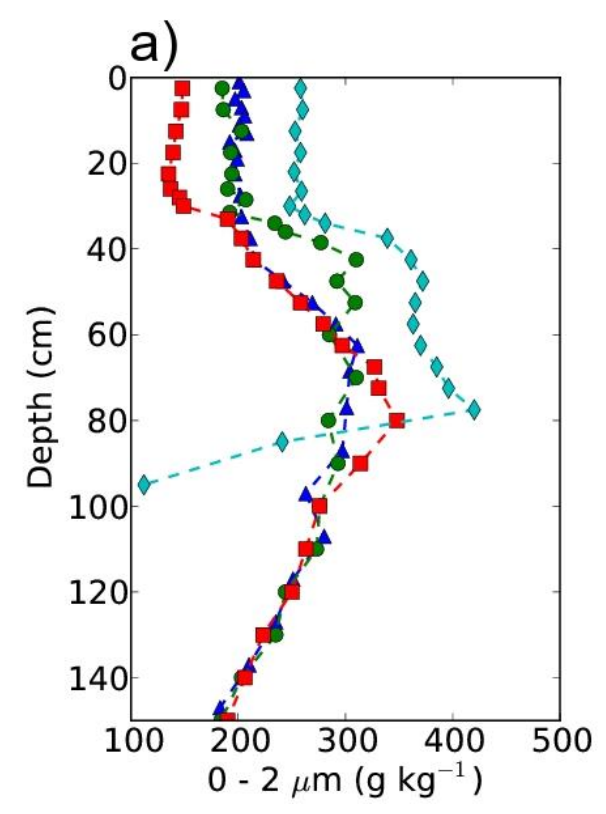

b)

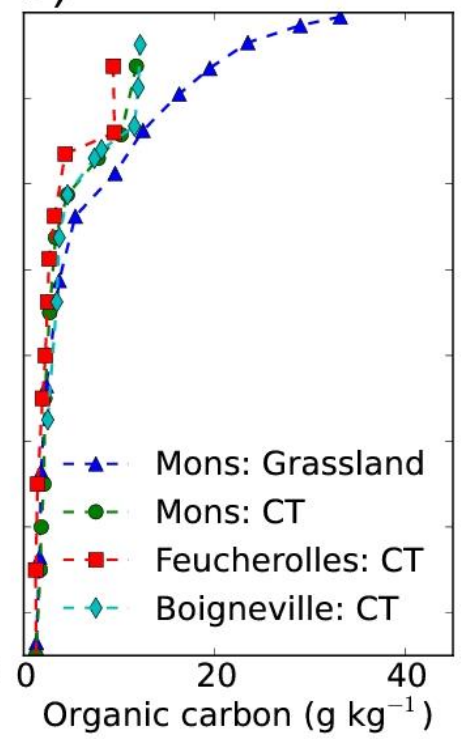

c)

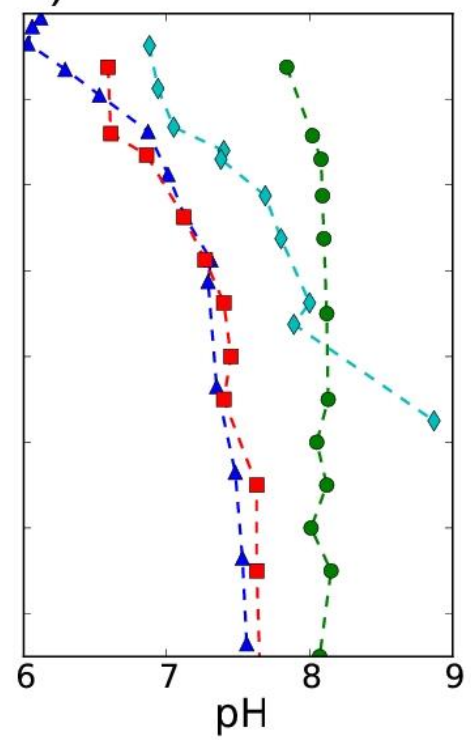


a)

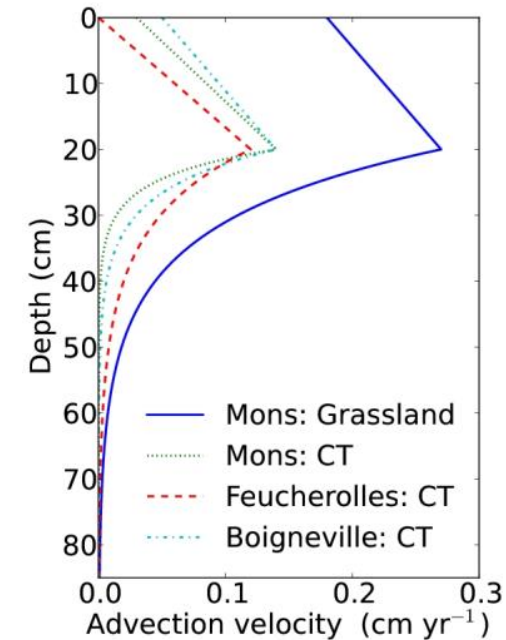

b)

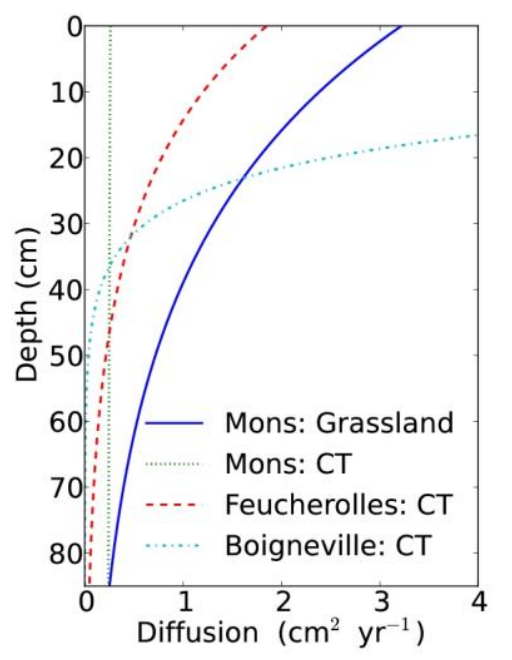


a)

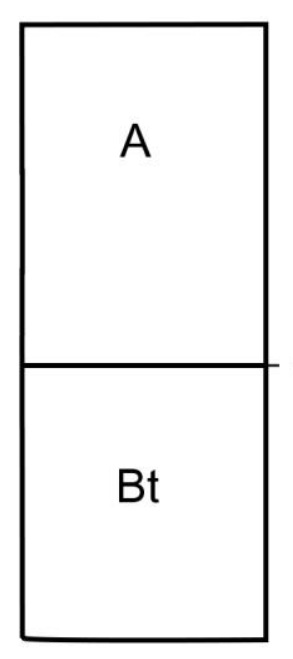

b)

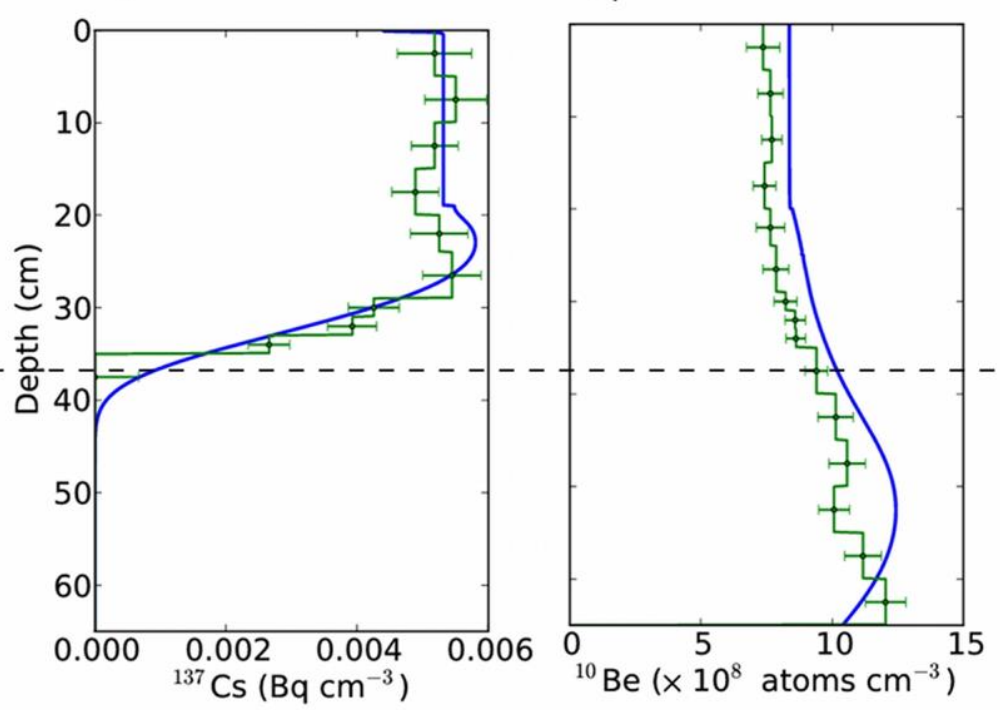


a)

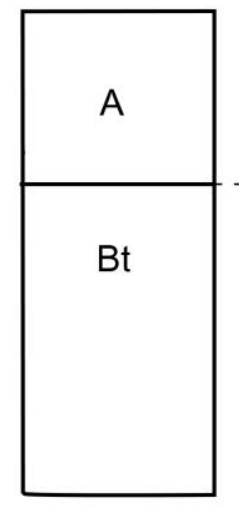

b)



c)

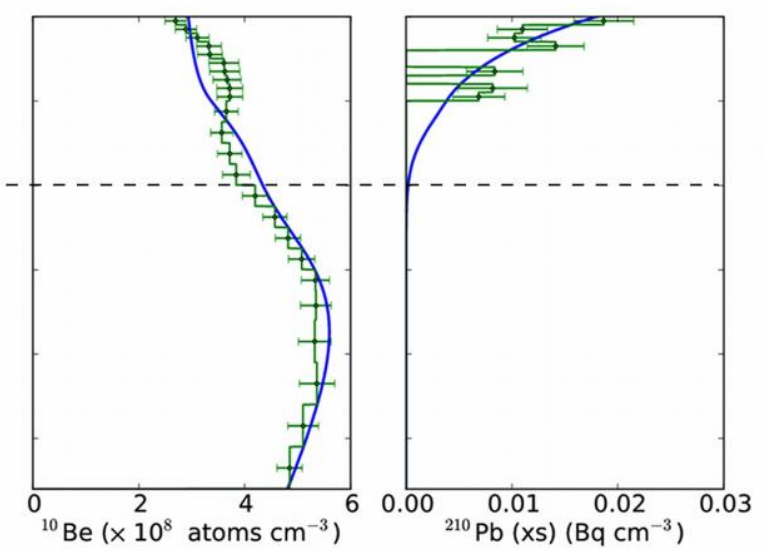


a)

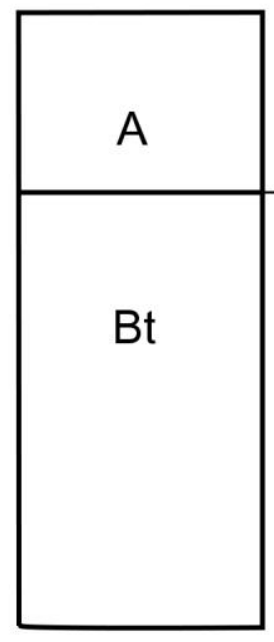

b)

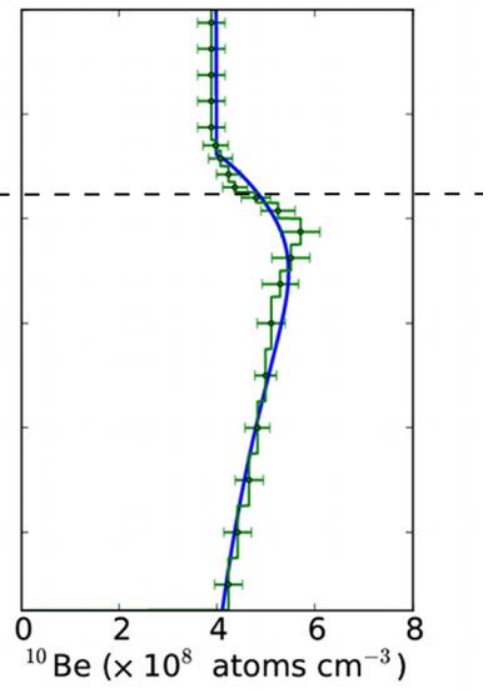


a)

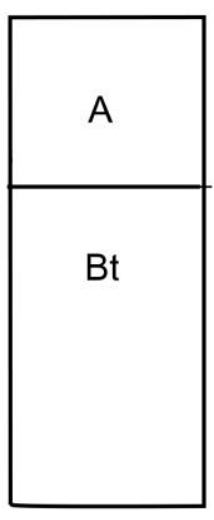

b)

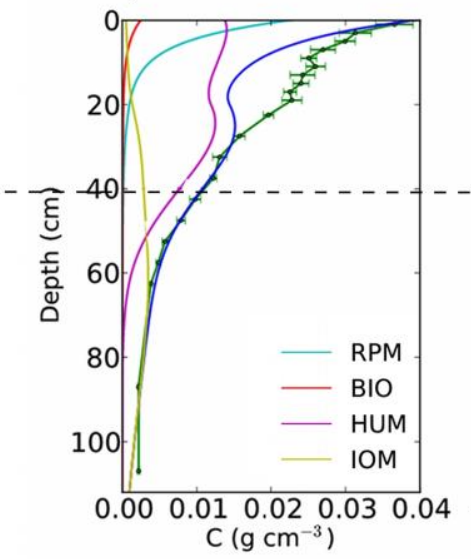

d)

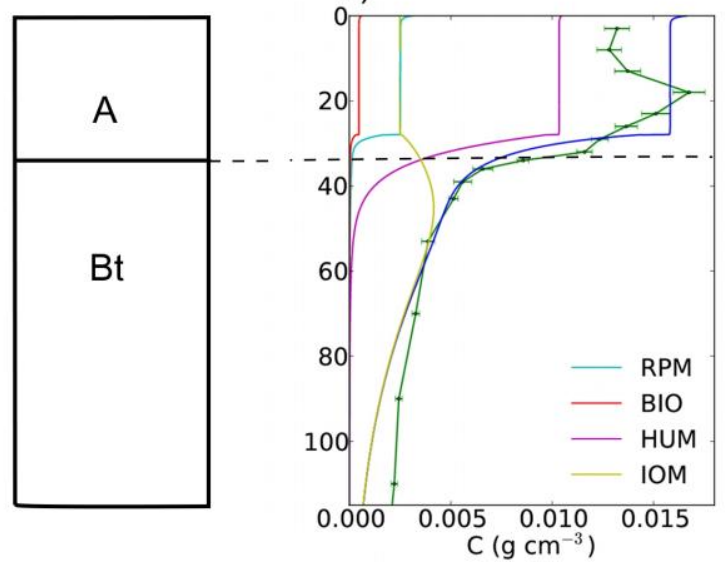

a)

b)

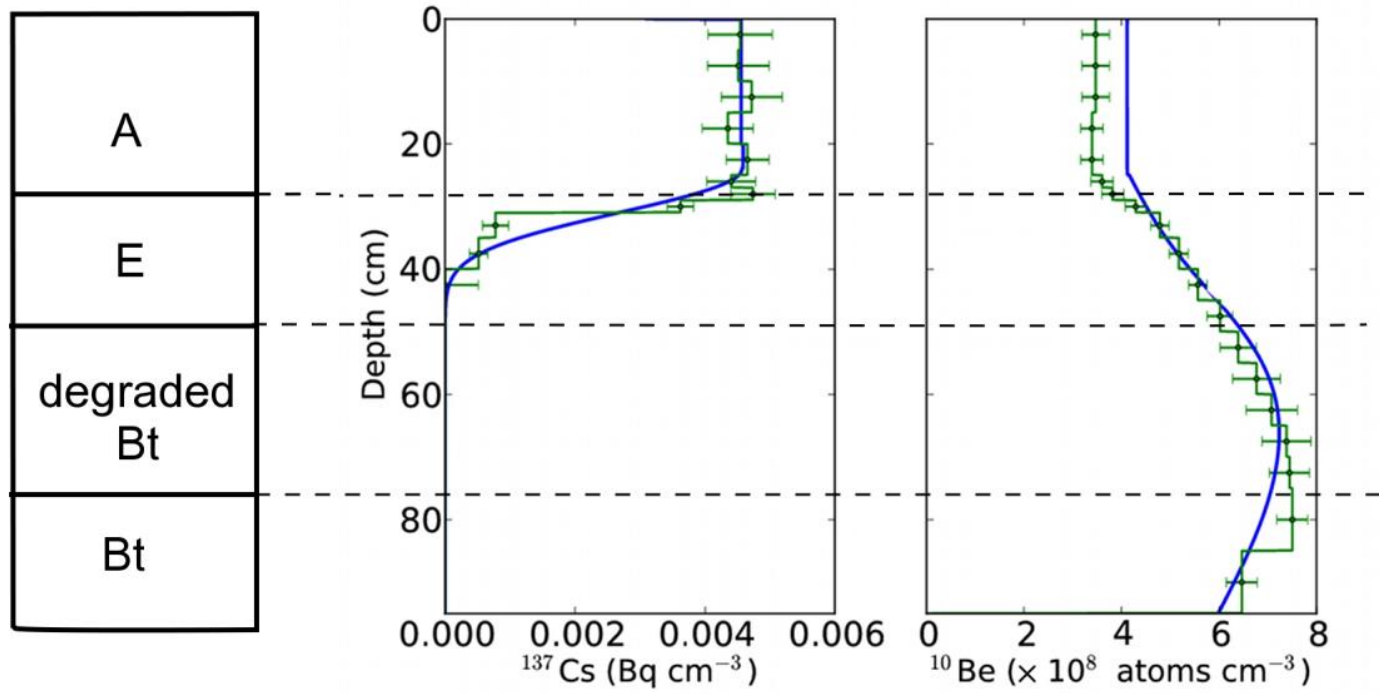

c)

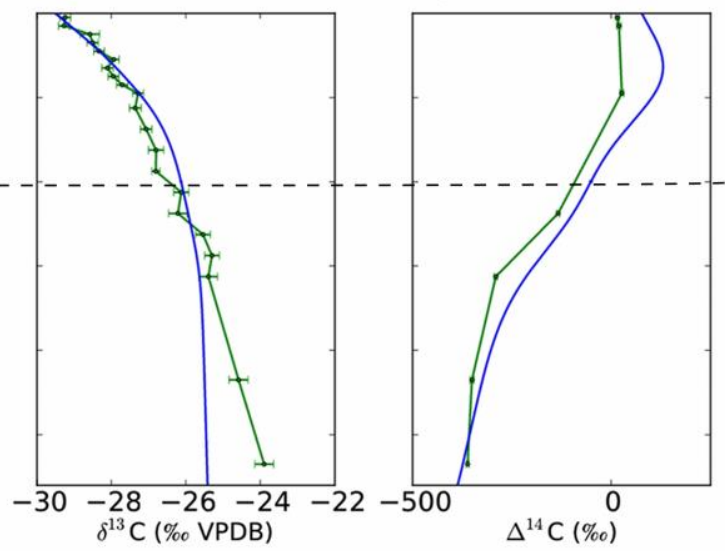


a)

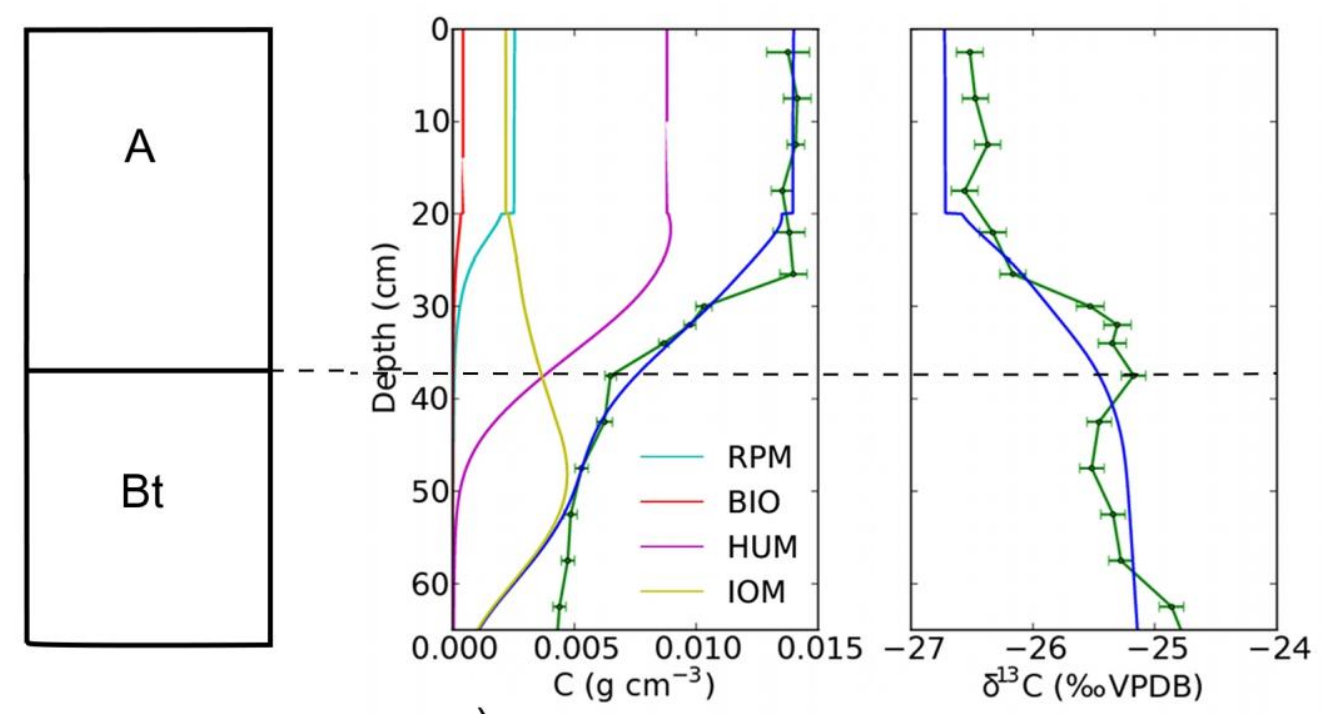

c)



b) 
a)

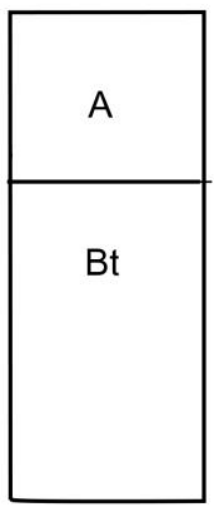

b)

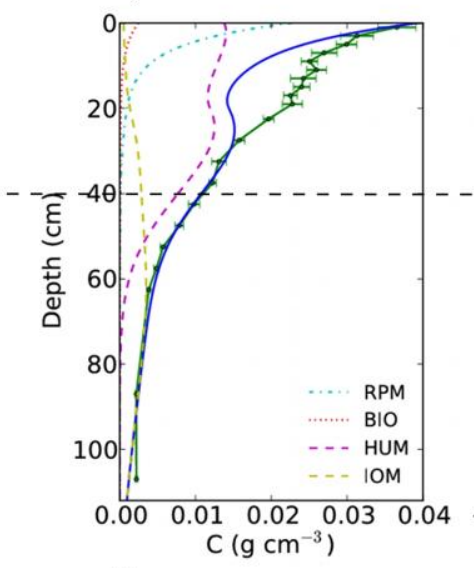

c)

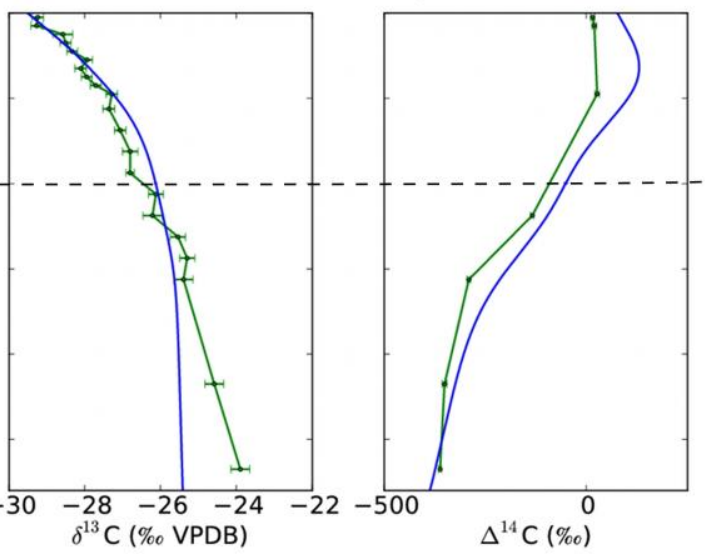

d)

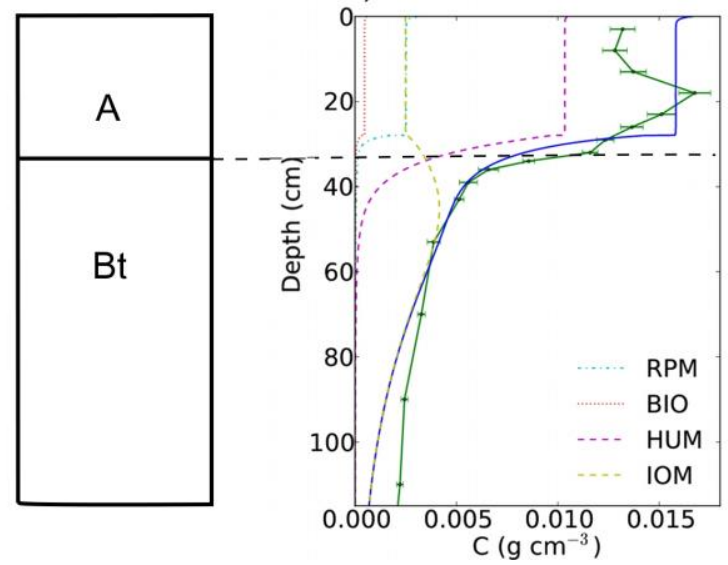


a)

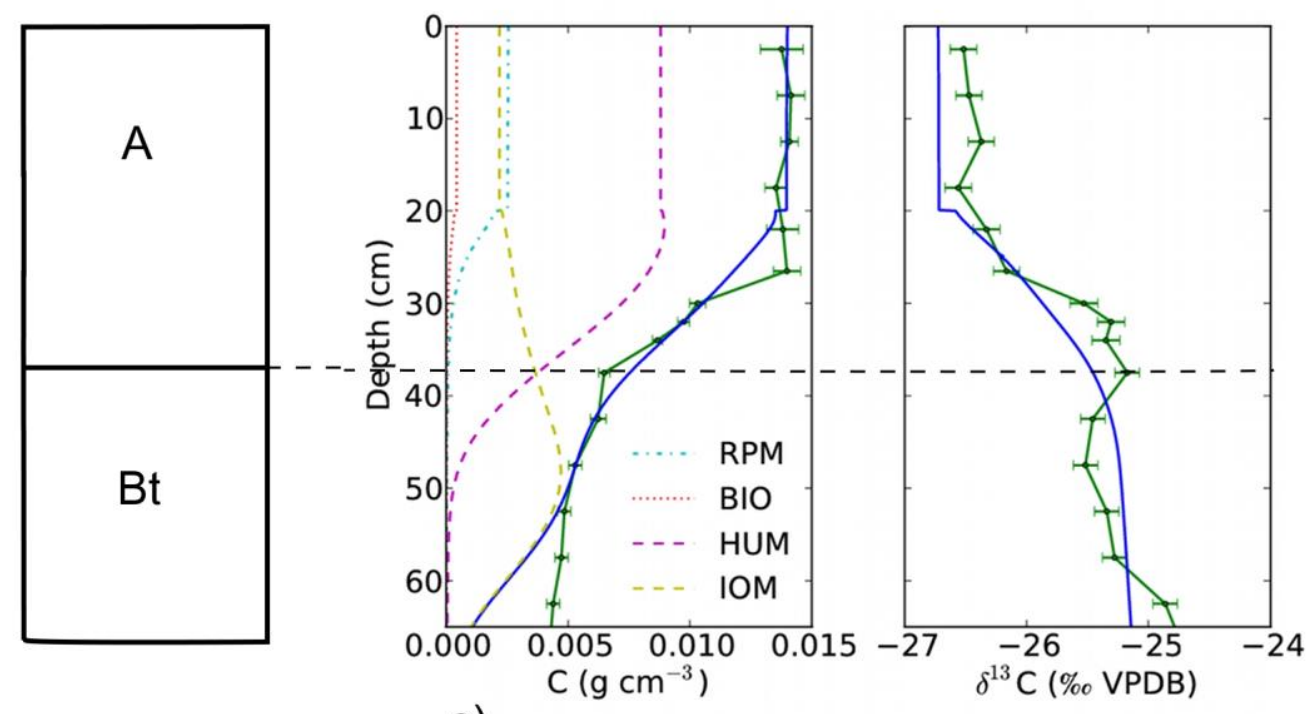

c)

b)

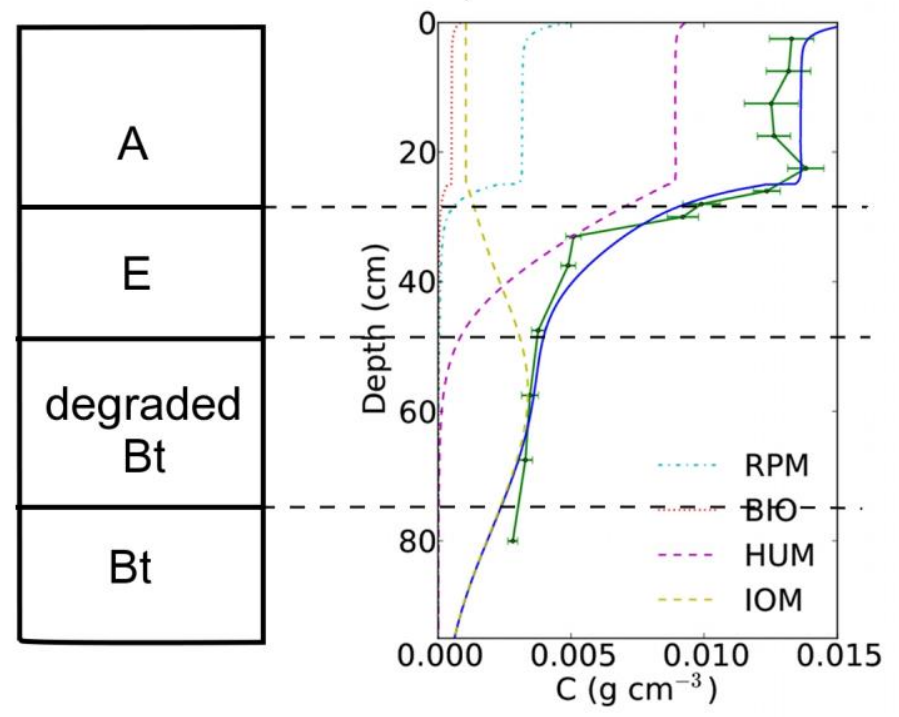


a)
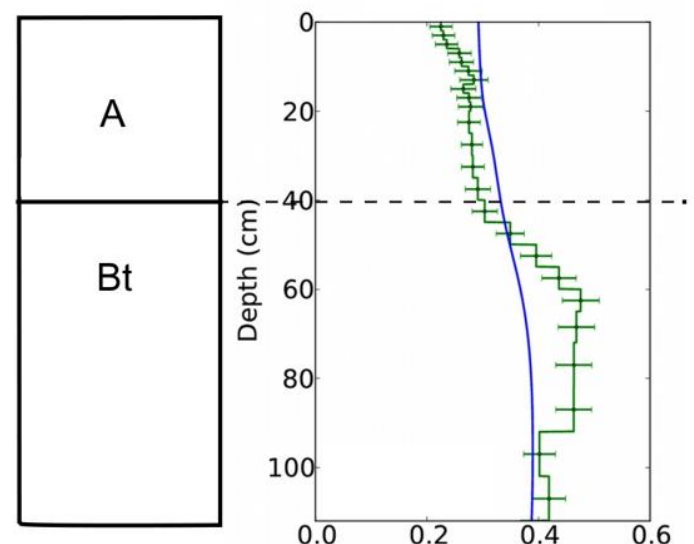

C) $0-2 \mu \mathrm{m}\left(\mathrm{g} \mathrm{cm}^{-3}\right)$

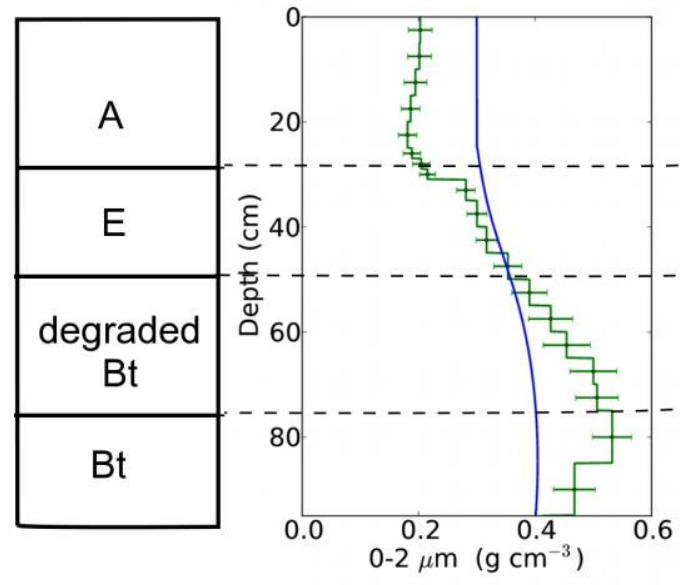

b)
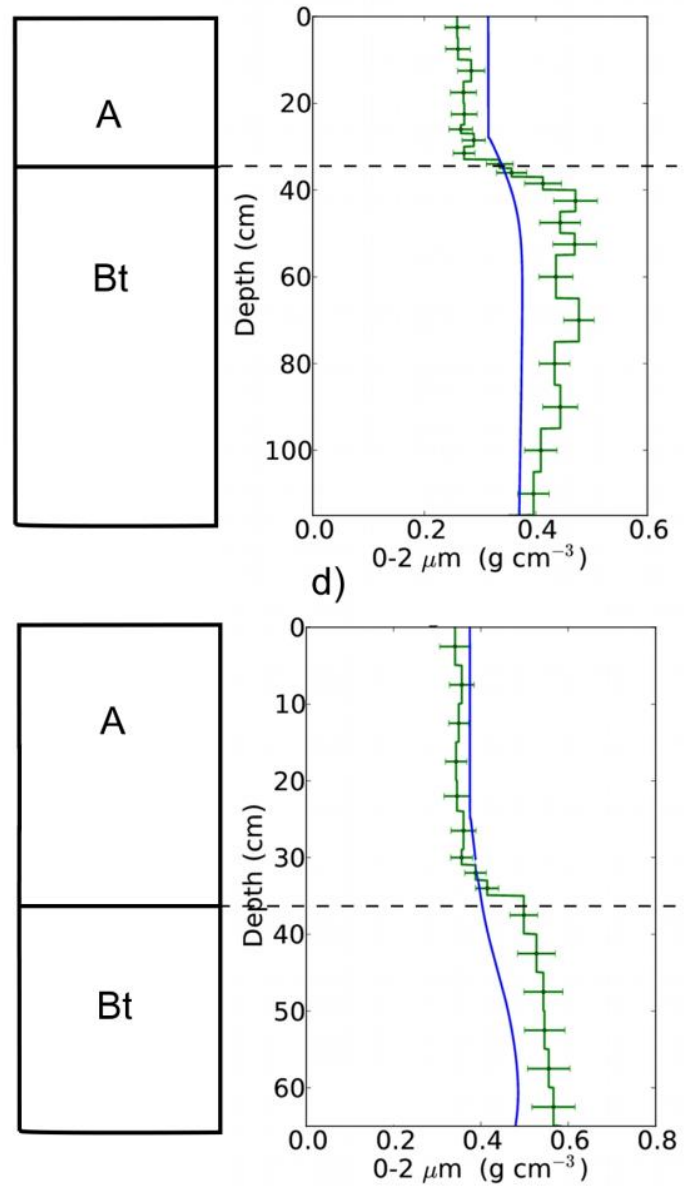

